\title{
Predicting extreme rainfall events over Jeddah, Saudi Arabia: Impact of data assimilation with conventional and satellite observations
}

\author{
${ }^{1}$ V.Yesubabu, ${ }^{2}$ C.V.Srinivas, ${ }^{1}$ Sabique Langodan and ${ }^{1}$ Ibrahim Hoteit \\ Corresponding Author: Ibrahim Hoteit \\ Email:ibrahim.hoteit@,kaust.edu.sa \\ Phone:+966 128080344
}

1. Department of Earth Sciences and Engineering, King Abdullah University of Science and Technology (KAUST), Thuwal 23955-6900, Saudi Arabia.

2. Radiological Safety and Environment Group, Indira Gandhi Centre for Atomic Research, Kalpakkam 603102, India.

This article has been accepted for publication and undergone full peer review but has not been through the copyediting, typesetting, pagination and proofreading process, which may lead to differences between this version and the Version of Record. Please cite this article as doi: 10.1002/qj.2654 


\begin{abstract}
The impact of variational data assimilation for predicting two heavy rainfall events that caused devastating floods in Jeddah, Saudi Arabia is studied using the Weather Research and Forecasting (WRF) model. On 25 November 2009 and 26 January 2011, the city was deluged with more than double the annual rainfall amount caused by convective storms. We used a high resolution, two-way nested domain WRF model to simulate the two rainfall episodes. Simulations include control runs initialized with National Center for Environmental Prediction (NCEP) Global Forecasting System (GFS) data and 3-Dimensional Variational (3DVAR) data assimilation experiments conducted by assimilating NCEP prepbufr and radiance observations. Observations from Automated Weather Stations (AWS), synoptic charts, radar reflectivity and satellite pictures from the Presidency of Meteorology and Environment (PME), Jeddah, Saudi Arabia are used to assess the forecasting results. To evaluate the impact of the different assimilated observational datasets on the simulation of the major flooding event of 2009, we conducted 3DVAR experiments assimilating individual sources and a combination of all data sets. Results suggest that while the control run had a tendency to predict the storm earlier than observed, the assimilation of profile observations greatly improved the model's thermodynamic structure and lead to better representation of simulated rainfall both in timing and amount. The experiment with assimilation of all available observations compared best with observed rainfall in terms of timing of the storm and rainfall distribution, demonstrating the importance of assimilating different types of observations. Retrospective experiments with and without data assimilation, for three different model lead times (48, 72 and 96-h), were performed to examine the skill of WRF model to predict the heavy rainfall events. Quantitative rainfall analysis of these simulations suggests that 48 -h lead time runs with assimilation of all observational data provide best statistical scores.
\end{abstract}

[Keywords: Flash Flood, Jeddah, WRF model, Data Assimilation, 3DVAR]

This article is protected by copyright. All rights reserved. 


\section{Introduction}

Flash floods are hazardous hydro-meteorological phenomena with potential to cause heavy damage in urban areas. In recent years, major cities in the Kingdom of Saudi Arabia (KSA), including Jeddah (25 November 2009, 30 December 2010, 26 January 2011) and Riyadh (03 May 2010, 17 November 2013), experienced devastating flash flood events that caused extensive damage in terms of human life and infrastructure (Haggag and El-Badry, 2013; Almazroui, 2013; Al-Khalaf and Basset, 2013). These flooding events were triggered by rapid development of runoff due to intense rainfall produced by mesoscale convective storms over short spans of time (Haggag and El-Badry, 2013). Such storms are often composed of individual convection cells, called mesoscale convective systems (MCSs), embedded in synoptic disturbances (Lee et al., 1998). Jeddah is the major commercial and industrial center of the Kingdom and a gateway for pilgrims to the two holy mosques in Mecca and Medina. A major amount of annual rainfall ( $63 \%)$ occurs mainly in the winter months due to thunderstorms (Shwehdi, 2005).

A review of previous studies (Kahana, 2004; Krichak et al., 2012; De Vries et al., 2013) indicates that the major contribution to rainfall in the western part of Saudi Arabia is associated with a southeastward propagating synoptic scale system from the Mediterranean region, called the Red Sea Trough (RST). The RST refers to a tongue shaped low pressure trough system, extending from the equatorial Africa to the East Arabian Peninsula, towards the Eastern Mediterranean. When the system is accompanied by mid-latitude upper tropospheric trough, it can trigger intense convection, and may lead to heavy precipitation events (Krichak, 2012; Shentsis et al., 2012; De Vries et al., 2013) in the Middle East. This phenomenon is commonly known as Active Red Sea Trough (ARST). Haggag and El-Badry (2013) simulated the Jeddah 
heavy rainfall event (2009) using the mesoscale meteorological model version 5 (MM5) and reported the development of a low pressure by latent heat release and cyclogenesis induced by the Hijaz mountain range, which lead to enhanced low-level convergence and increased convection over Jeddah. De Vries et al., (2013) identified six dynamical factors associated with ARST and attributed the heavy rainfall on 25 November 2009 over Jeddah to ARST. Prediction of such organized convective phenomena and associated extreme rainfall is often difficult because of scarcity of crucial observations for defining accurate initial conditions. Assimilation of vertical sounding may improve the thermodynamics, which in turn should lead to better representation of the signature of the ARST in the model (De Vries et al., 2013)

Accurate prediction of spatio-temporal distribution of weather phenomena, such as convective storms and related rainfall, requires the use of high-resolution mesoscale models, the availability of high density of observations equipped with sophisticated assimilation techniques, and the best combination of parameterization schemes (Colle and Mass, 2000; Mass et al., 2002). Almazroui (2011a) studied the sensitivity of the Regional Climate Model (RegCM) with respect to horizontal resolution for heavy rainfall events in Jeddah and reported that the use of a highresolution domain may not systematically improve the simulation of precipitation in all cases. A shortcoming of the study is the lack of data assimilation which is considered to be very important for determining accurate initial conditions for numerical weather models (Mass et al., 2002; Liu and Rabier, 2002; Navon, 2009). In particular, variational techniques, such as three/fourDimensional Variational Data Assimilation (3/4-DVAR) became very popular in recent years in operational weather forecasting (Courtier et al., 1998; Kalnay, 2003) due to their advantages of physics-based assimilation satisfying the model's dynamic and thermodynamic constraints, and for their capability of effectively combining conventional and non-conventional data from 
different sources and times. Though four-dimensional data assimilation techniques such as 4DVAR and Ensemble Kalman Filters (EnKFs) are generally proven to be more effective than 3DVAR, they remain computationally quite demanding. In addition to the use of advanced assimilation schemes, previous mesoscale assimilation studies (e.g. Ruggiero et al., 1996; Liu and Rabier, 2003; and Faccani and Ferretti, 2005) demonstrated the need of dense observational networks for assimilation. Compared to surface observations, assimilation of profile observations of temperature and humidity, and wind derived from satellites and radiosonde (Anderson, 2000; Zhang and Ni, 2005; Bradley et al., 2012; Tuanjie et al., 2013; Yesubabu et al., 2014) and Doppler radar data (Xiao et al., 2005; Xiao et al., 2007; Wang et al., 2013; Sun and Wang, 2014) was shown to significantly reduce the initial errors in model analysis, leading to better representation of convective instability, and consequently better prediction of the storms intensities. In Saudi Arabia the establishment of Doppler radars is however still in experimental stage, and availability of conventional observations is quite scarce.

Satellite observations play a key role in providing crucial information for weather forecasting in data scarce regions. The positive impact of satellite data assimilation in simulating heavy rainfall events has been documented by several previous studies (English et al., 2000; Chen et al., 2008; Rakesh et al., 2009). In particular, satellite radiances are identified as a vital source of observations for filling the gaps in data sparse areas. Satellite radiances are assimilated in regional models in many operational weather centers (e.g., Derber and Wu, 1998; McNally et al., 2000) using 3/4-DVAR techniques. Apart from these data sources, Atmospheric Motion Vectors (AMV) from geostationary satellites, such as GOES, Meteosat, and Kalpana (Cherubini et al., 2006; Wang et al., 2006; Yesubabu et al., 2014), available as part of the operational global 
observational database, could also be a potential source of information for improving the initial conditions of weather models.

Even though the impact of data assimilation on the prediction of heavy precipitation events has been successfully demonstrated for many regions, such work has not been yet conducted for the Middle East. Here, we attempt to fill this gap. Our objective is to assess the impact of data assimilation with a high-resolution Weather Research and Forecasting (WRF) model on shortrange forecasts of heavy rainfall events over Jeddah. 3DVAR is adopted for assimilation in our study because it is an effective method to provide reliable forecasts at reasonable computational resources compared to the advanced 4D methods (e.g., 4DVAR and EnKFs). This study is organized as follows. Section 2 describes the heavy rainfall events considered in the study. Section 3 presents the model domain and its configuration, the assimilation methodology, the assimilated data, and data used for the evaluation of model results. Section 4 reviews the synoptic situation for each rainfall event. Section 5 presents the simulation results, emphasizing eventual implications of data assimilation on the model forecasting skills. Section 6 offers a summary and conclusions.

\section{Description of Heavy Rainfall Episodes}

The two heavy rainfall events considered in this study occurred over the city of Jeddah in the winter months (25 November 2009 and26 January 2011). The city lies in the middle of the eastern coastal plains of the Red Sea between latitudes $21.41^{\circ} \mathrm{N}$ and $21.75^{\circ} \mathrm{N}$, and longitudes $39.08^{\circ} \mathrm{E}$ and $39.33^{\circ} \mathrm{E}$ (Katibah, 2012). To the east, the city is surrounded by hills and the Asir mountain ranges to the southeast. This region has a typical semi-arid climate (Köppen, 1936) characterized by hot and humid summers with average daily temperatures of $39^{\circ} \mathrm{C}$ from May to 
October. The winters are cooler and relatively wet with temperatures below $30^{\circ} \mathrm{C}$ and relatively high humidity ( $70 \%$ ). In summer, northwesterly winds blow along the whole length of the Red Sea (Jiang et al., 2009), with Jeddah experiencing the same wind pattern. In winter (October to March), north to northwesterly winds blowing from the Mediterranean and Saharan high region form a convergence zone over the central Red Sea region with southeasterly (SE) winds blowing from the Gulf of Aden (Pedgley, 1966; Langodan et al., 2014). These SE winds are the low-level northeast Asian monsoon winds topographically diverted by the mountain ranges of east Africa and southwest Arabian Peninsula.

The flooding of the city of Jeddah in November 2009 was described by civil defense officials as the worst in 27 years. As of January 2010, more than 150 people were reported killed and more than 350 were reported missing (Haggag and El-Badry, 2013). The second event, less damaging but comparably spectacular, occurred one year later, during January 2011 (Almazroui, 2013). The operational regional weather prediction models run by the Kingdom's meteorological agency, the Presidency of Meteorology and Environment (PME), failed to capture the intensity of the storms. While PME succeeded to forecast the 26 January 2011 event four days ahead, it failed to forecast the November 2009 event (Yousef et al., 2012).

\section{Data and Methodology}

Simulations were conducted with the Advanced Research WRF (ARW) model (Skamarock et al., 2008) version 3.4 and assimilation experiments with the 3DVAR component of the WRF Data Assimilation system (WRFDA). Three nested domains with respective horizontal resolutions of 27, 9and $3 \mathrm{~km}$ (Figure 1), and 36 vertical levels are used. The model topography (terrain elevation, soil information, land use and land cover) is defined from the USGS global data set 
available with WRF, at arc '2 min' resolution for the first and second domains, and '30 sec' resolution for the inner domain $(3 \mathrm{~km})$. The following physics configurations were used; Goddard Ensemble scheme for microphysics, Dudhia shortwave radiation scheme, RRTM long wave radiation scheme (Mlawer et al., 1997), YSU non-local scheme for PBL turbulence (Hong et al., 2006), and the NOAH scheme for land surface processes (Chen and Dudhia, 2001). Kain-Fritsch (KF-Eta) mass flux scheme (Kain and Fritsch, 1993) was used for cumulus convection for the two domains with 27 and $9 \mathrm{~km}$. No cumulus scheme was used for the inner $(3 \mathrm{~km})$ domain. These physics schemes were selected as they have been identified to produce the best predictions of extreme weather events over Jeddah and nearby regions (e.g., Srinivas et al., 2012; Deng et al., 2013; Deng et al., 2015; Yesubabu et al., 2014). In the control run (CTL), the model is initialized at 0000 UTC 24 November 2009 for the first event (2009) and at 0000 UTC 25 January 2011 for the second event (2011) with $0.5^{\circ}$ x $0.5^{\circ}$ resolution NCEP Global Forecasting System (GFS) analysis and then integrated up to 48 hours while updating the boundary conditions from GFS forecasts at 6-hour intervals. For assimilation experiments, we have used 3DVAR to assimilate observations in 6-hourly cycles.

In 3DVAR, an "optimal" estimate of the atmospheric state is obtained at any given analysis time by iteratively minimizing a cost function measuring the distance between the model simulation and the available observations, and the distance of the solution to the background (Ide et al., 1997; Courtier et al., 1998; Barker et al., 2004). The WRFDA system was first developed based on the incremental formulation of 3DVAR (Barker et al., 2005) and later extended to 4DVAR and Hybrid Algorithms (Huang et al., 2009; Barker et al., 2012). The 3DVAR cost function is defined as 


$$
J(x)=J^{b}+J^{0}=\frac{1}{2}\left(x-x^{b}\right)^{T} B^{-1}\left(x-x^{b}\right)+\frac{1}{2}\left(H x-y^{o}\right)^{T}(E+F)^{-1}\left(H x-y^{o}\right),
$$

where $x$ denotes the analysis state, $x^{b}$ is the background state, $H$ is the observation operator and $\mathrm{y}^{\mathrm{o}}$ is the observation. $B, E$ and $F$ are the background, observation (instrumental) and representativity error covariance matrices, respectively. In this approach, the state analysis, $x^{a}$, is thus produced by combining observations, model forecasts, their respective errors and physical laws. In general, there are two ways for applying 3DVAR in WRF; Cold-start and Cyclic modes. The cold start mode refers to single assimilation with background obtained from a different model, and the cyclic approach uses the forecast from the driving model (WRF) as the background for the next cycle (Routray et al., 2014). The cyclic approach has the advantage of providing balanced analyses that are more consistent with the forecast model (Xiao et al., 2005). In the present study, we have used the cyclic approach in which WRF is initialized with GFS analyses and the 6-hour model forecast is used as background (first guess) to assimilate observations in 6-hourly cycles.

The background error covariance, $B$, plays a crucial role in representing the forecast error (Routray at el., 2014) over the chosen domain. In this study, $B$ is estimated based on the standard National Meteorological Centre (NMC) method (Parrish and Derber, 1992) in which the forecast error covariances are estimated from forecast differences that are relevant over the analysis time. $B$ is computed by only considering perturbations from the peak winter month (December) to better represent the climatology of the winter season in the background error covariance. The WRF model is run by daily cycles with 24-hour forecasts initialized at 0000 and 1200 UTC for a period of one month during December 2008. The forecast differences between 12 and 24-hours are used as model perturbations to estimate $B$ with the NMC method.

This article is protected by copyright. All rights reserved. 
The assimilated observations are operationally available prepbufr global observations from the NCEP Atmospheric Data Project (ADP) archives and Advanced Microwave Sounding Unit (AMSU) Radiances from NOAA's ATOVS. The prepbufr data comprise land surface, marine surface, radiosonde, pilot-balloon and aircraft reports from the Global Telecommunications System (GTS), AMV's from geostationary satellites, profiler and radar derived winds, SSM/I oceanic winds and NESDIS satellite wind data. Full description of the prepbufr dataset is available at http://rda.ucar.edu/datasets/ds337.0. The spatial distribution of all assimilated observations at the time of assimilation is shown in Figure 2. The profiles data used in assimilation experiments mainly comprise the radiosonde and pilot balloon observations. For radiance assimilation experiments, we use radiances from the AMSU. The derived information of temperature and humidity profiles from the AMSU instruments have been widely used for data assimilation in NWP since 1998 and have been proven to play crucial role in improving model forecasts. AMSU is basically a multi-channel radiometer, designed to receive and measure radiation to derive temperature and humidity profiles of the atmosphere. The AMSU system consists of two separate modules: AMSU-A and AMSU-B which are on board on a series of NOAA polar orbiting satellites. The AMSU-A is a cross-track scanning, total power microwave radiometer with swath width of $2343-\mathrm{km}$, and operating in 15 -channels $(23.8 \mathrm{GHz}-89.0 \mathrm{GHz})$. The instrument is primarily designed for deriving atmospheric temperature profiles from the earth surface up to $45 \mathrm{~km}$ height. Whereas AMSU-B is a continuous line scanning, total power radiometer designed to provide radiance measurements in five channels. The instrument is intended for providing vertical profiles information of humidity from the surface of the Earth to about $12 \mathrm{~km}$ height. Out of the five channels of AMSU-B, three channels span on strong water 
vapor absorption line at $183.31-\mathrm{GHz}$. The other two channels (89 and $150 \mathrm{GHz}$ ) are window channels that penetrate through the atmosphere to the surface of Earth.

Assimilation of the satellite radiances directly into the WRFDA system requires a fast radiative transfer model (RTM). In general, the RTM includes forward, tangent linear and adjoint models. The forward model simulates the radiances with the help of representation of model atmosphere, further the RTM adjusts simulated radiances very close to observed radiances using the variational methodology. One of the most commonly used RTM models for WRFDA is Community Radiative Transfer Model (CRTM). The CRTM is formulated based on the preprocessed data sets at Joint Center for Satellite Data Assimilation (JCSDA) center in NOAA. It can simulate channel specific radiances for both infrared and microwave sensors. A summary of its developments and details of the algorithms can be obtained from Weng et al., (2005). For the present study, we also used the CRTM for direct assimilation of AMSU radiances in radiance assimilation experiments. Satellite radiances are subjected to systematic biases which need to be corrected before assimilation. The radiance biases can be parameterized as described in Liu et. al., (2012)

$$
\widetilde{H}(x, \beta)=H(x)+\beta_{0}+\sum_{i=1}^{N_{p}} \beta_{i} p_{i}
$$

where $\beta_{0}$ is a constant component of the total bias, and $p_{i}$ and $\beta_{i}$ are the $i^{\text {th }}$ of $N_{p}$ predictors and corresponding bias correction coefficients respectively. The bias correction coefficients $\beta$ are channel dependent and can be estimated offline (Harris and Kelly, 2001), or can be updated using a variational bias correction (VarBC) scheme (Derber and Wu, 1998). In the present study, bias correction is carried out using the inbuilt bias correction coefficients for the first assimilation cycle. For the subsequent cycles, VarBC estimated from the previous cycle was 
used as bias correction coefficients. In AMSU-A only sounding channels 5-9 are assimilated in WRFDA because of their sensitivity to tropospheric and lower stratospheric temperatures, while the other channels are more sensitive to the land surface (channels 1-4, 15) and upper troposphere (channels 10-14). Similarly, in AMSU-B, only sounding information from channels 3-5 are assimilated as channels (1-2) are highly sensitive to the land surface.

To evaluate the forecast results from experiments with and without assimilation of observations, we use surface synoptic charts, surface station and upper air radiosonde, radar reflectivity and rainfall observations from PME, Jeddah and TRMM 3B42 Version 7 rainfall estimates. The TRMM and CMORPH rainfall estimates are available at $0.25^{\circ} \times 0.25^{\circ}$ resolutions. The PME TITAN radar technical details and precipitation algorithm are documented by Sinkevich and Terrence (2013). Since the TRMM rainfall estimates failed to detect the observed rainfall reported by weather stations, we have also compared the results with CMORPH rainfall estimates (Joyce et al., 2004), a multi-satellite precipitation product from passive microwave and infrared data available at resolution of $0.25^{\circ} \times 0.25^{\circ}$. Several studies, e.g. Dinku et al., (2006), Dinku et al., (2010), and Habib and Nasrollahi (2009), reported that a bias in rainfall estimates are associated with the underlying surface, especially with regard to complex terrain such as hill surfaces and arid land surfaces. Almazroui (2011b) calibrated the TRMM estimates with available rain-gauge data over the Kingdom during 1998-2009 and reported that rainfall in the southwest region of Saudi Arabia is underestimated during the winter months.

\section{Synoptic situation}

During the first storm event that occurred on 25 November 2009, the PME surface observatory at King Abdulaziz International (KAI) Airport in Jeddah recorded accumulated rainfall of $140 \mathrm{~mm}$ 
during 0600-1200 UTC, the highest rainfall ever recorded in a day in Jeddah. In winter, dominant pressure systems controlling the climate of the western Arabian Peninsula are Sudan low, Arabian and Saharan high. Due to the presence of Sudan low, northwesterly winds blowing from the Mediterranean form a convergence zone over the central Red Sea (at $18^{\circ} \mathrm{N}$ ) with southeast winds of northeast Monsoon regime flowing through the southern Red sea (Pedgley, 1966). The migration of the convergence zone basically depends on the strength of the opposite flow and associated pressure systems.

The synoptic meteorological condition as shown in the PME surface chart from 1200 UTC of 23 to 1800 UTC on 24 November (Figure 3a,b) indicates movement of a low-pressure system from Sudan to the northeastern part of the Red Sea. At the same time two high-pressure systems, one over the west of Sudan and another northeast of the Red Sea are identified on either side of the Red Sea, block the low-pressure system from moving northwards. After 30 hours, the highpressure systems were relocated towards west and east of the existing low-pressure system. This allows the low-pressure system to migrate northward. Simultaneously a small high-pressure system was present in southern Red Sea. Within a period of 6 hours, the southern high-pressure system moved westwards and the low-pressure system got intensified and lay over the central Red Sea (Figure 3c). Subsequently, the low-pressure system further intensified in the following 6 hours and lead to the development of a deep convection zone along the eastern Red Sea region. This convection culminated into heavy rainfall over Jeddah before the low-pressure system had completely passed through the Tokar gap region (the northeastern part of Sudan) between 06000900 UTC. It was finally seen over the southwest-southern part of Sudan in the chart at 1200 UTC 25 November (Figure 3d). The METEOSAT satellite imagery from PME reveals that a large number of convective cells/squall lines (as shown in Figure 4) followed the trajectory of 
low pressure system, first moving eastward from Sudan to the Medina mountains during 09001500 UTC on 24 November and producing a downpour on Medina. Thereafter, the movement of convective cells changed its direction and moved towards Jeddah, following the movement of the low-pressure system. This low pressure associated with converging winds facilitated moisture buildup from the Red Sea. The upward lifting of the moisture by vertical motion under the complex topography of southeastern of Jeddah had resulted in heavy rainfall.

The second heavy rainfall event of 26 January, 2011 occurred under the same prevailing wind conditions as in the 2009 event and led to rainfall amounts of 19 and $111 \mathrm{~mm} \mathrm{day}^{-1}$, respectively over KAI Airport (north of Jeddah) and ARAMCO (south of Jeddah) AWS station. Satellite images taken two days prior to the event reveal that a couple of convective cloud bursts occurred in the surrounding region of Jeddah. These cloud bursts are associated with the passage of convective cells from northeast Africa towards Jeddah, causing the surrounding atmosphere to become highly unstable with high CAPE values of $1225.2 \mathrm{~K} \mathrm{~J} \mathrm{~kg}^{-1}$. The highest cape values are recorded at a radiosonde station in Jeddah. The PME synoptic chart shows the same pattern of movement of low pressure as in the previous episode along Jeddah and the neighboring region (as shown in Figure 5). The major convective outbreak for this event occurred in the southern part of Jeddah and the passage of convective cloud cells (from satellite and radar images) were seen over Jeddah between 0600 and 0900 UTC on 26 January.

\section{Numerical Experiments}

Two sets of numerical experiments were performed with and without assimilation of observations using the WRF model. The first set of experiments was designed to investigate the impact of assimilation of the various sets of observations for capturing the convective storms in 
terms of timing, location and intensity; and the second set to evaluate the ability of the WRF model to simulate the two heavy rainfall episodes at different lead times.

In the first set of experiments, a control and five assimilation experiments were carried out for the 2009 event to assess the impact of assimilation of observations on the model forecasts. In the control run of each case, the GFS analysis (at 0000 UTC on 24 November 2009) is used as the initial condition. In the assimilation experiments, the model is initialized at 0000 UTC as in CTL, WRF 6-h forecast is then used as first guess in 3DVAR and various observations are assimilated to produce initial conditions (VAR analysis) for the next cycle. Therefore, 3DVAR is run in four analysis cycles $(0600,1200,1800$ and 0000 UTC) in which the forecast from the previous cycle is taken as first guess for the subsequent cycle. We have conducted five experiments each assimilating different sets of observations, namely VARSFC (surface observations), VARAMV (atmospheric motion vectors), VARPRO (sounding observations), VARRAD (AMUS-A and AMSU-B Radiances), and VARALL (all available observations). Since the sounding observations are available twice a day, VARPRO was carried out in two assimilation cycles following Hsiao et al. (2013). The details of these assimilation experiments are listed in Table 1.

To evaluate the skill of the WRF model in predicting the two heavy rainfall events, second sets of experiments were conducted retrospectively with different lead times. For the first event in 2009, three experiments (using GFS analysis and corresponding forecasts) with and without 3DVAR assimilation were initialized at 0000 UTC on 22, 23 and 24 November 2009 and integrated up to 0000 UTC on 26 November 2009 to obtain 96, 72, 48-h lead time predictions, respectively. Similarly, for the second rainfall event in 2011, the same three retrospective experiments were conducted by initializing the model at 0000 UTC on 23, 24 and 25th of 
January 2011 with lead times 96, 72, 48-h. The details of the retrospective forecast experiments are listed in Table 2.

\section{Results and Discussion}

The results and discussion section is organized in two sub-sections. First, we analyze the influence and merits of the different sets of observations in improving mesoscale forecasts of the 2009 rainfall event; second we discuss the ability of the model to simulate the two heavy rainfall events with different lead times. The results are presented from the innermost $(3 \mathrm{~km})$ domain.

\subsection{Impact of data assimilation on WRF simulations}

In this section, six simulations are conducted for the 2009 rain event, comprising of CTL and five assimilation experiments using different sets of observations. The CTL experiment is initialized at 0000 UTC 24 November 2009 with GFS analysis, and all VAR experiments are initialized at 0000 UTC 23 November 2009 with GFS analysis. Using WRF-6h forecasts as first guess, the assimilation in VAR experiments are carried out in four cycles (i.e., 0600, 1200, 1800

UTC 23 November 2009 and 0000 UTC 24 November 2009), and then a 48-h forecast is obtained by integrating WRF for each VAR experiment. The results are presented in five parts: Part 1 investigates the differences in the estimated initial model fields resulting from 3DVAR assimilation, Part 2 examines the space-time evolution of the simulated fields, Part 3 compares simulated reflectivities with the PME radar images, Part 4 analyzes the storm movements and intensity, and Part 5 compares the simulated rainfall with available observations.

\subsubsection{Differences in initial fields with and without assimilation}

This article is protected by copyright. All rights reserved. 
As discussed in Section 3, observations from heterogeneous sources are assimilated into the model. It is therefore essential to examine how these observations modified the corresponding model fields. Scatter diagrams are shown in Figure 6, comparing the assimilated observations against the model first guess and the corresponding fields after 3DVAR analysis for the dynamical and thermo-dynamical parameters, such as temperature (T), zonal (U) and meridional (V) wind components, and mixing ratio (Qv) at the end assimilation cycle at 0000 UTC 24 November 2009. The plots show lesser scatter after assimilation, suggesting significant reduction of errors after 3DVAR analysis compared to the first guess. The extent of improvement for the various variables after assimilation is somehow related to the amount of assimilated observations. Of the available observations, 54\% of Surface Synoptic, 50\% of METARS, 90\% of Atmospheric motion vectors, $86 \%$ of Soundings and $88 \%$ of AMSU Radiances are used in the assimilation cycle. The possible reason for the rejection of many ground based observations are explained by Schwitalla et al. (2011) as due to the mismatch between the observations height with model heights for many of the surface observations. The extent of statistical error reduction is about $50 \%$ in the surface temperature (at $2 \mathrm{~m}$ ) after assimilating surface synoptic data, and about $0.2^{\circ} \mathrm{C}$ in mean bias and $0.50^{\circ} \mathrm{C}$ in $\mathrm{RMSE}$ for metar stations. From the surface data assimilation, one can see that the underestimation of the initial temperature at the model lowest level is corrected by $0.50^{\circ} \mathrm{C}$, and meager changes were observed in the wind and water vapor fields. The relatively small changes in the wind field in this case could be also due to difference in observation and model heights, as well as larger differences (between observation and first guess) than the observational error in specific humidity and wind. Assimilation of AMVs significantly decreased the wind errors. The error reductions in the zonal and meridional winds between the first guess and 3DVAR analysis are about $0.5-0.8 \mathrm{~m} \mathrm{~s}^{-1}$ and $2-2.5 \mathrm{~m} \mathrm{~s}^{-1}$ in terms of 
bias and RMSE, respectively, at all model levels. The zonal winds exhibit large errors compared to the meridional component. The differences in RMSE with assimilation of profile observations (.i.e., radiosonde and pilot balloon) at all model levels are $1.6 \mathrm{~m} \mathrm{~s}^{-1}, 0.2^{\circ} \mathrm{C}$ and $0.2 \mathrm{gkg}^{-1}$ for $\mathrm{U}$ and $\mathrm{V}$ components, temperature, and water vapor mixing ratio, respectively (the scatter plots for $\mathrm{V}$ wind, and water vapor are not shown). Large differences are found in the wind, especially the meridional component, with less spread and RMSE than the first guess values. With the radiance data, the major differences are found in channel 5 of AMSU-B, with temperature differences of $1.2^{\circ} \mathrm{C}$ in RMSE and $0.1^{\circ} \mathrm{C}$ in bias, and channel 6 of AMSU-A with differences of $2^{\circ} \mathrm{C}$ in RMSE and $0.1^{\circ} \mathrm{C}$ in bias. Assimilation clearly reduces the scatter for all the examined variables, reflecting significantly better agreement with the data.

To illustrate the extent of incremental improvement of the model fields after assimilation, the spatial distribution of the differences in surface fields between CTL and VARALL are analyzed for two assimilation cycles corresponding to 1200 UTC 24 November and 0000 UTC 25 November. Differences in temperatures (shaded) and sea level pressure (SLP; contour) at $2 \mathrm{~m}$ along with differences in the wind field at $10 \mathrm{~m}$ and relative humidity (shaded) taken from the model inner domain are presented in Figure 7. At 1200 UTC of 24 one can clearly notice an increase in temperature over northeast Africa (Egypt and Sudan) and the eastern coastal plains of the Red Sea by $3{ }^{\circ} \mathrm{C}$, and a decrease over the mountains by $2^{\circ} \mathrm{C}$ and over the northern part of Red Sea by $0.5^{\circ} \mathrm{C}$ (Figure 7a). The relative humidity decreased along the east coast of Egypt and Sudan, and along the Asir Mountains, and increased by 10 to $20 \%$ in central Sudan and northwestern and west-central parts of the Kingdom (Figure 7c). The wind differences exhibit an increase in strength of the northerly flow over Egypt, convergences over Medina and the Hijaz Mountains, and a southeasterly flow over the west central part of the Kingdom. At 0000 UTC 25 
November the temperature increments are about $4^{\circ} \mathrm{C}$ in the western parts, $1{ }^{\circ} \mathrm{C}$ in the northern parts, and $-2{ }^{\circ} \mathrm{C}$ along the coast north of Jeddah. This caused the humidity to decrease by 10 to $20 \%$ in the western parts, and $5 \%$ in the central and northern parts. The wind differences with and without assimilation at 0000 UTC 25 November (Figure 7e), suggests that southerly winds in the southern part and northwesterly winds in the eastern and northeastern parts are strengthened by $\sim 2-3 \mathrm{~m} \mathrm{~s}^{-1}$, whereas, westerly winds in the northern Red Sea are weakened by 3 $\mathrm{m} \mathrm{s}^{-1}$ after assimilation. The analysis increments further indicate higher warming, lesser humidity and converging wind flow characteristics after assimilation relative to CTL. Differences in SLP suggest low-pressure system over the Medina region strengthened (by $-0.5 \mathrm{hPa}$ ) in VARALL, leading to the development of strong synoptic condition favorable for convection near the Medina Mountains (Figure 7a,d).

\subsubsection{Time variation of surface parameters}

Time variations of simulated surface parameters, namely dry bulb temperature, relative humidity, wind speed and direction, from all experiments during the 48-h forecast (0000 UTC 24 - 0000 UTC 26 November 2009) are compared with surface synoptic observations provided by the PME surface observatory $\left(21.67^{\circ} \mathrm{N}, 39.15^{\circ} \mathrm{E}\right)$ in Jeddah (Figure 8). The diurnal evolution of temperature along with synoptic observations indicate that the maximum temperature during the first day (24 November) is underestimated in all experiments by $\sim 2^{\circ} \mathrm{C}$, though relatively less (by $1^{\circ} \mathrm{C}$ ) in VARALL. There is a sudden drop (by $5^{\circ} \mathrm{C}$ ) in temperature observations during 0400 0700UTC on 25 November that is also well reproduced by VARALL, whereas CTL simulated temperature drops 3 to 4 hours earlier than observed, and this is reflected in all other CTL fields. VARPRO is found to be the next best experiment, underestimating the temperature drop by $2^{\circ} \mathrm{C}$.

The other two assimilations experiments, VARSFC and VARAMV, reproduced the fall in

This article is protected by copyright. All rights reserved. 
temperature by $1^{\circ} \mathrm{C}$ and 2 hours earlier than the CTL, whereas VARRAD failed to capture the observed fall. The time evolution of relative humidity $(\mathrm{RH})$ indicates that there is nearly a 3hours lead in the simulated RH drop, with a 15\% drop occurring between 0600 and 1000 UTC on the first day in all experiments except for VARAMV, which exhibits considerable lead in the dip of the RH cycle. An abrupt fall by $10 \%$ and subsequent increase by $30 \%$ in RH are simulated by VARALL between 0000 and 0600 UTC of the second day (25 November), suggesting that this experiment well captured the timing of the event. CTL exhibited similar behavior, but 3-hours prior to the observed drop. VARSFC and VARPRO showed little drop and then $20 \%$ increase in the RH, while VARAMV and VARRAD simulated a gradual increase in RH between 0000 and 0600 UTC on 25 November, without showing any drop in the RH.

In the case of surface winds, the observations indicated steady winds before the passage of the storm i.e., between 0000 and 0300 UTC on 25 November, calm conditions during 0400-0700 UTC on 25 November, and then a sudden increase in the wind speed by $7 \mathrm{~m} \mathrm{~s}^{-1}$. VARALL and VARPRO produced similar trends with an overestimation of $4 \mathrm{~m} \mathrm{~s}^{-1}$. The CTL exhibited similar features but overestimated wind speed by $2 \mathrm{~m} \mathrm{~s}^{-1}$ with three hours lead time. VARSFC and VARAMV overestimated the winds by $50 \%$ during the storm hours. Overall, VARPRO and VARALL better simulated the time variation compared with the other experiments, remarkably reproducing important features during the passage of the storm, such as a sudden increase in relative humidity and a drop in temperature and sharp rise in wind speed. The observed wind direction during the passage of the storm clearly indicates a change in wind direction from southwest to northeast and then backs to southeast. Except for VARALL and VARPRO, all other experiments indicate a change in wind direction 3-hours earlier than the observed winds. The wind direction trends in VARALL and VARPRO are also consistent with the observed trends. 
The surface pressure variations during the storm event are well simulated by VARALL, in terms of timing and magnitude.

To examine the timing of the simulated heavy precipitation in the different experiments, the evolution of the hourly simulated rainfall from the model is compared with the corresponding observed PME surface rainfall (shown in Figure 8f). In all experiments, the model mean hourly rainfall was computed as the average of four grid points centered about the PME station. The temporal variation in the PME hourly rainfall observations indicates that the convection slowly started at around 0600 UTC on 25 November. There was a spell of thundershowers for two hours, which produced nearly $65 \mathrm{~mm}$ of rain after three hours at 1200 UTC on 25 November, and another spell of thundershowers at 1600 UTC on 25 November. Most experiments showed earlier initiation of convection, 2 to 6 hours than the observed event. CTL and VARRAD experiments showed much earlier ( $\sim 8$ hours) convection. VARPRO and VARSFC respectively simulated the rainfall 5 and 4 hours earlier than the observed event, whereas VARSFC and VARALL successfully captured the exact timing. The 24-hour simulated rainfall was found to be lower in CTL, VARAMV, VARSFC, VARPRO, and slightly higher in VARRAD. It can also be seen that the VARALL simulated rainfall is in better agreement with the observed rainfall than all other experiments, both in terms of timing and amount.

The Skew-T diagram for the radiosonde location of KAI Airport, from the CTL and VARALL at 0900 UTC and 2100 UTC on 24 November 2009 are shown in Figure 9. Simulated temperature profiles indicate that the model did not reproduce the observed inversion until $850 \mathrm{hPa}$ in both runs. However, the profiles better matched the radiosonde above $850 \mathrm{hPa}$. At both times, VARALL better matched the observed profiles between 600 and $550 \mathrm{hPa}$, leading to stronger convection than in CTL. The model in both experiments failed to capture the observed trends in 
dew point at 0900 UTC between 900 and $850 \mathrm{hPa}$, even though VARALL captured the trend at the surface level. The observed dew point profile shows a rapid increase and then an immediate decrease, indicating a sudden increase and decrease in moisture content. The model dew point profile is better simulated by VARALL than CTL at 2100 UTC with respect to vertical variation of lower atmospheric moisture content. The vertical variations in dew point between 400 and 200 hPa levels at both times (0900 UTC and 2100 UTC 24) are also better reproduced in VARALL. The Skew-T diagram suggests that wind speeds are slightly better simulated by VARALL, while winds at different levels exhibit similar directional patterns in both experiments.

\subsubsection{Time evolution of vertical distribution of dynamical and thermodynamical parameters}

To analyze the initiation and development of the convective event, time-height section of horizontal and vertical winds at the location of the storm $\left(21.6^{\circ} \mathrm{N}, 39.15^{\circ} \mathrm{E}\right)$ as simulated by CTL and VARALL are presented in Figure 10. CTL indicates a 3-hour early development of the convective event with weaker intensity (vertical winds $\sim 3-7 \mathrm{~m} \mathrm{~s}^{-1}$ ) and less vertical extent (limited to $400 \mathrm{hPa}$ ) than VARALL. The horizontal flow in CTL also exhibits stronger wind shear above $500 \mathrm{hPa}$ relative to VARALL. The stronger wind shear impedes the convergence and development of the convection, leading to a weaker storm. The distribution of the wind flow suggests that VARALL accurately simulates the timing of the storm. VARALL vertical winds exhibit a slight tilt in the upper levels towards the east of the storm center suggesting entrainment, which persisted for about 3 to 4 hours. It also indicates a development of deep convection characterized by strong vertical winds / updrafts $\left(\sim 9 \mathrm{~m} \mathrm{~s}^{-1}\right)$ extending up to $200 \mathrm{hPa}$ layer. The initiation of convection at around 0000 UTC and its intensification by 0600 UTC 25 November are well simulated by VARALL. The time-height section of simulated equivalent potential temperature and maximum reflectivity are presented in Figure 11. In WRF, reflectivity

This article is protected by copyright. All rights reserved. 
fields are computed from model simulated hydrometeors using the empirical relations described in Koch et al. (2005). Stable thermal stratification before 0000 UTC 25 November and unstable conditions between 0000 UTC and 0700 UTC can be clearly seen from the temperature structure in both CTL and VARALL. However, both temperature and reflectivity variations exhibit an early development of deep convection by nearly 3hours in the case of CTL (at 0300 UTC) compared to VARALL (at $0700 \mathrm{UTC}$ ). The instability is limited to a vertical region of $10 \mathrm{~km}$ in CTL compared to a deeper unstable layer extending up to $15 \mathrm{~km}$ in VARALL. The reflectivity distribution shows much deeper, wider and more intense convective cells in VARALL. Analysis of a time-height section of reflectivity, horizontal and vertical winds suggests that VARALL simulated much deeper, stronger convection over Jeddah, which in turn lead to a quasi-stationary system, producing heavy rainfall. These results are consistent with the previous studies of De Vries et al., (2013) and Haggag and El-Badry (2013) who reported that a strong upper level tropospheric instability and associated deep moist convection resulted in a quasi-stationary mesoscale convective system over Jeddah.

Temporal evolution of thermodynamic indices, such as Convective Available Potential Energy (CAPE), K-Index, Total Totals (TT) index for the KAI airport radiosonde location as diagnosed from the model outputs and estimated from observations are presented in Figure 12. The indices are plotted at different stages of the storm (i.e. pre, mature, during and post storm occurrence). The observational estimates show high values of CAPE, K-Index, TT-Index in the daytime (1100 UTC 24 Nov - 0300 UTC 25 November) indicating development of convectively unstable atmosphere during the pre-storm occurrence hours. Since the observations are available at 0000 UTC / 1200 UTC alone, further information on the exact timing of the peak growth of convection could not be inferred from the observations. However, the observations show the 
high value at 1200 UTC of 24 and a minimum value at 1200 UTC of 25 November in good agreement with the model values. From the model simulation, it is very clear that the storm starts accumulating the CAPE values from $10 \mathrm{~J} / \mathrm{kg}$ at around $0900 \mathrm{UTC}$ of 24 and it reached maxima of $3500 \mathrm{~J} / \mathrm{kg}$ at around $1300 \mathrm{UTC}$ before it starts decreasing from $2000 \mathrm{UTC}$ to a value of 24 and reaching a minimum value of 25 at 0600 UTC. This indicates that the model is able to predict well the thermodynamic features of the storm, such as the formation, deepening/mature stage and also dissipating stage of the storm. The CAPE and other indices from simulations generally agree well with the observational estimates and the convective instability from these indices is maximum in VARALL, followed by VARPRO, VARSFC, VARAMV, VARRAD and CTL. Further, the duration of thermal instability is maximum in VARALL ( $\sim 18$ hours) followed by VARPRO ( 15 hours), VARSFC, VARAMV, VARRAD (14 hours each), and CTL ( 1200 UTC). These differences in the duration of convection and maximum CAPE should influence the intensity of the storm and the associated rainfall in the different experiments. There is a three hours lag in reaching the storm's intensity, after which the assimilated model values well matched the observed indices. While VARALL and VARRAD exhibit relatively higher estimates, the CTL run shows lower estimates of the above parameters. VARALL and VARPRO produced realistic comparisons of various thermodynamic indices between 1200 UTC on 24 and 1200 UTC on 25 November 2009. The abrupt increase in CAPE and K-Index in the simulations indicates the likely occurrence of a storm, the sustainment of the maxima for few hours indicates the development of the storm, and the sudden fall of its values confirms the occurrence of the storm during 0200-0600 UTC on 25 November. The CTL experiment simulated the occurrence of the storm 2 to 3 -hours earlier than the assimilation runs.

\subsubsection{Comparison of simulated reflectivity analysis with PME Radar}

This article is protected by copyright. All rights reserved. 
The intensity of the convective storm is analyzed based on the simulated maximum reflectivity in the horizontal and vertical planes. WRF simulated reflectivities at 0000 UTC (Figure 13.1), 0300 UTC (Figure 13.2), 0600 UTC (Figure 13.3) and 0800 UTC (Figure 13.4.) on 25 November 2009 from (a) CTL, and (b) VARALL along with the corresponding (c) PME TITAN radar images are shown in Figure 13. Radar reflectivity suggests movement of a band of convective cells from north to south, which merge with small convective cells formed over the sea. The movement of the convective bands clearly shows the storm passage during 0600 to 0900 UTC on 25 November. Both CTL and VARALL reproduce well the passage of the storm over Jeddah. The movement of the convective cells in CTL run is 3 hours faster than VARALL. The development of mesoscale convective cells in the Red Sea, and their migration towards Jeddah before they get merged are well simulated by VARALL than CTL. The convective cells that originated over the Red Sea have relatively larger size and more realistic patterns in VARALL compared to CTL. The changes in thermodynamic profile in VARALL after assimilation, possibly resulted in improved representation of the structure of convective cells, and hence a more accurate simulation of the convective system and associated rainfall.

\subsubsection{Simulated wind flow and vorticity}

To analyze the dynamics of the storm, simulated $850 \mathrm{hPa}$ winds and vorticity (shaded) from CTL and VARALL at 0300 UTC, 0600 UTC, 0700 UTC and 0800 UTC on 25 November 2009 are presented in Figure 14. The black circle in Figure 14 shows the city region of Jeddah. In both experiments, strong southerly winds over the southern part of the domain and north/ northwesterly winds over the northwestern part of the domain are observed at 0300 UTC on 25 November. There are clear indications of converging winds with development of certain cyclonic vorticity along the coastline of Jeddah. This suggests the presence of a severe weather 
disturbance that is simulated away from Jeddah with positional differences, i.e., $50 \mathrm{~km}$ and 100 $\mathrm{km}$ north of Jeddah in CTL and VARALL, respectively. Strong positive vorticities are found over Jeddah in VARALL, indicating strong convergence at lower levels. The area of strong vorticity in CTL associated with low-level convergence is moved to the south of Jeddah. The movement of cyclonic winds is found to be faster in CTL, while the movement of the system in VARALL is slow and quasi-stationary over Jeddah during the subsequent time intervals of 0600 to 0800 UTC on 25 , resulting in increased amount of total rainfall in VARALL.

Upper air circulation and divergence associated with the convective storm are analyzed at 300hPa from CTL and VARALL experiments (shown in Figure 15) at 0300 UTC, 0600 UTC, 0700 UTC and 0800 UTC on 25 November 2009. Both experiments simulated strong westerly winds between 0300 and 0600 UTC. Thereafter, the wind flow changes to southwesterly and week anti-cyclonic winds are seen over the region of strong divergence north of Jeddah. This upper air divergence would further facilitate strong surface convergence, leading to intensification of the storm. Similar to the $850 \mathrm{hPa}$ winds in CTL, the anti-cyclonic winds in CTL at $300 \mathrm{hPa}$ that passed over Jeddah between 0300 and 0600 UTC exhibit strong divergence, which facilitated the development of severe convection towards the south of Jeddah. In VARALL, a concentrated cyclonic wind (up to $300 \mathrm{hPa}$ ) is observed over Jeddah during 03000600 UTC of 25 November, which remained stationary for three to four hours with a strong divergence in neighboring regions. These features suggest that VARALL produced highly localized but strong convergence associated with cyclonic circulation extending till $300 \mathrm{hPa}$, leading to an occurrence of isolated very heavy rainfall over Jeddah.

\subsubsection{Rainfall Analysis}

This article is protected by copyright. All rights reserved. 
For the 2009 event, the heavy rainfall occurred over Jeddah between 0600 UTC and 1200 UTC on 25 November 2009 (Almozri, 2012). Simulated spatial distributions of 24-hour accumulated rainfall $(\mathrm{mm})$ on 25 November from all experiments are compared with the observed rainfall estimates of TRMM-3B42 and CMORPH (Figure16). The circle in all panels of Figure 16 indicates the location of the city of Jeddah. The rainfall distribution from TRMM estimates exhibit moderate rainfall over Jeddah with two peaks, one of 90 mmday $^{-1}$ occurring south of Jeddah and the other of 80 mmday $^{-1}$ near the city of Medina (about $100 \mathrm{~km}$ northeast of Jeddah). TRMM estimates (40-60 mmday $\left.{ }^{-1}\right)$ fail to capture the intensity of the heavy rainfall over Jeddah. The CMORPH estimates revealed the storm's actual intensity with peak rainfall exceeding 120 mmday $^{-1}$ in the northeastern part of Jeddah; the second peak is located in the southeastern part. CTL simulated a 24-hour rainfall peak $50 \mathrm{~km}$ south of Jeddah over the eastern Red Sea, with rainfall of about $40-50$ mmday $^{-1}$ over Jeddah. The major rainfall band in CTL is concentrated along the east coast of the Red Sea over a stretch of $150 \mathrm{~km}$ starting from Jeddah. The other two rainfall bands are found over Mecca and the eastern part of Rabigh. In VARSFC, VARAMV, and VARPRO the heavy rainfall is distributed mainly along the ocean sectors to the north and southwestern side of Jeddah with peak amounts of $140 \mathrm{mmday}^{-1}, 120 \mathrm{mmday}^{-1}$, and $90 \mathrm{mmday}^{-1}$, respectively over the ocean sectors, and 60-120 mmday ${ }^{-1}, 100-120$ mmday $^{-1}, 80-90$ mmday $^{-1}$, respectively over Jeddah. The VARRAD shows a dense rainfall band aligned from Jeddah to northeast with highest rainfall simulated among all experiments and peak rainfall of 120-140 mmday $^{-1}$ distributed over Jeddah. Rainfall simulated with VARRAD indicates a better spatial distribution with higher rainfall over the land sectors and lower rainfall over the ocean sectors, comparing well with CMORPH data. VARRAD simulated a peak rainfall amount of 90-100 mmday $^{-1}$ located roughly $20 \mathrm{~km}$ to the east of Rabigh. The rainfall pattern from VARRAD over 
Jeddah compares well with the PME-RADAR convective rain bands. However, it shows an unusual northeastward extension of rainfall unlike TRMM/ CMORPH estimates and fails to represent the rainfall distribution in the eastern, southeastern and southern sectors of Jeddah. The VARALL run shows a primary heavy rainfall band over Jeddah and a second band of lesser intensity (60-70 mmday $\left.{ }^{-1}\right)$ distributed towards the north of Jeddah. This experiment also indicates heavy rainfall of 100-120 mmday ${ }^{-1}$, with a single peak concentrated over the west coast and the northern part of Jeddah. Overall, VARALL showed the best agreement with the observations in terms of pattern and intensity. Similar features are simulated for the second rainfall event (2011) for which it is found that VARALL better simulated the rainfall distribution in intensity and location (not shown). The above results indicate over predictions of rainfall with assimilation of satellite radiances only and under prediction of rainfall (though improved over control runs) with assimilation of conventional observations. To understand the role of satellite radiances in the assimilation, a separate experiment assimilating all observations except the radiances data ( $\mathrm{SFC}+\mathrm{PRO}+\mathrm{AMV})$ is conducted. It has been found that the prediction of the various meteorological parameters as well as the spatial distribution of rainfall are not improved as seen in VARALL after exclusion of the radiance data in assimilation (Figure not shown). The combination of radiance data with convectional data seems to produce a compensating effect leading to improvement in rainfall predictions due to improvement in model thermodynamics in VARALL over SFC, PRO and AMV in which radiance was not used. These results corroborate with the recent study by Greeshma et al (2015) where relatively stronger convection and higher rainfall for tropical cyclone predictions were reported in simulations with the application of radiance data along with conventional observations compared to simulations using just conventional data alone.

This article is protected by copyright. All rights reserved. 


\subsection{Lead time Prediction Experiments}

Results in the previous sections clearly indicated that the VARALL experiment with assimilation of all sources of observations provided best simulations of the two heavy rainfall episodes. This section examines the capability of WRF to simulate the rain episodes with different lead times (96, 72, $48 \mathrm{~h}$ ) with CTL and VARALL. The results of the first rainfall event that occurred on 25 November 2009 (shown in Figure 17) suggest that for all test lead times (96, 72, 48 h), CTL predicted the heavy rainfall mainly to be distributed over the Sea south-southwest of Jeddah, with the best rainfall pattern obtained with the 48-h lead time run. However, CTL failed to simulate the land based heavy rainfall peak (80-110 mmday $\left.^{-1}\right)$ to the northeast of Jeddah. VARALL produced different rainfall patterns with different lead time runs. Out of 96-h lead time runs, VARALL produced two peaks of rainfall respectively distributed about $50 \mathrm{~km}$ to the north and $20 \mathrm{~km}$ to the south of Jeddah. In the 72 -h lead time run, the rainfall is distributed over northeast and east sectors of Jeddah with a peak rainfall of 140 mmday $^{-1}$ spreading over an area of approximately $100 \mathrm{~km}$ and an amount of rainfall of 80-110 mmday $^{-1}$ is simulated over Jeddah. In the 48-h lead time simulation the peak rainfall is distributed over Jeddah and up to $50 \mathrm{~km}$ to the south of Jeddah along the coast with extended rain bands to the east on the land portion. The rainfall distribution form VARALL with 48-h lead time compares well with the CMORPH rainfall estimates and provides a reasonable simulation while both 96-h and 72-h lead time simulations failed to capture the rainfall patterns as observed in the PME radar rain bands.

For the second heavy rainfall event that occurred on 26 January 2011 both TRMM and CMORPH data (shown in Figure 18) indicate the distribution of maximum rainfall over the

northeast of Jeddah with higher amounts $\left(70\right.$ mmday $\left.^{-1}\right)$ from TRMM compared to CMORPH (20 mmday $\left.^{-1}\right)$. These two data sets estimated a rainfall of about 30-40 mmday $^{-1}$ over Jeddah. 
However, the PME Radar rain bands show the heavy rainfall of 80-90 mmday $^{-1}$ distributed from northeast to southwest parts of Jeddah. It also indicates a second rainfall peak about $20 \mathrm{~km}$ north of Jeddah. In all the lead-time runs, CTL simulated the rainfall distribution to the extreme southeast of Jeddah, with some improvements in the 48-h lead time run. Rainfall in the 96-h lead run of VARALL is also simulated to the southeast of Jeddah. VARALL resulted in significant improvement in the $72-\mathrm{h}$ and 48 - $\mathrm{h}$ experiments by gradually bringing the rainfall in better agreement with the observed patterns. The simulated rainfall of VARALL with 48-h lead time is in best agreement in terms of distribution and intensity with the PME Radar data. Thus the results of the two rainfall events (2009 and 2011) clearly demonstrate that the 48-h lead time assimilation run (VARALL) better reproduced the observed features of the storm characteristics and rainfall.

The time evolution of rainfall at hourly intervals corresponding to the PME synoptic station $\left(21.67^{\circ} \mathrm{N}, 39.15^{\circ} \mathrm{E}\right)$ from the model and observations is presented for the first event (2009) in Figure19a. Rainfall in both 96-h experiments (CTL and VARALL) occurred in two spells, a small convective outbreak followed by a second spell, respectively 12 hours and 5-7 hours before the actual event. However, VARALL simulated higher rainfall and time lead of 2 hours relative to CTL. VARALL with 72-h lead time simulation exhibits similar trend, producing higher amount of rainfall and one hour closer to the observed. The assimilation run (VARALL) with 48-h lead time simulated realistic rainfall pattern, both in terms of quantity and timing. It also produced much higher rainfall than CTL. For the second event in 2011 (Figure 19b), as heavy rainfall was mainly concentrated over the central and southern Jeddah region, we have examined the model rainfall results for the weather station data located south of Jeddah i.e., ARAMCOAWS $\left(21.406^{\circ} \mathrm{N}, 39.1925^{\circ} \mathrm{E}\right)$. From the 96 -h lead time experiments it is found that 
both CTL and VARALL simulated the occurrence of an early rainfall $(10 \mathrm{~mm}$ in CTL; $2 \mathrm{~mm}$ in VARALL), roughly 24-h earlier than observed, with VARALL showing an increase of rainfall at 0300 UTC 26 January peaking to a quantity of $45 \mathrm{~mm}$ by 0800 UTC 26 January. Both 96-h lead time runs underestimated the rainfall and did not capture the timing of peak rainfall intensification. For the 72-h lead time runs, CTL produced a moderate rainfall of (60 mm) and 4 hours later than the actual event and VARALL simulated a very high rainfall $(\sim 160 \mathrm{~mm})$ roughly 3hours before the event. VARALL with 48-h lead time also showed a moderate rainfall over Jeddah on 1200 UTC 25 January, indicating an early initiation of the event about 20 hours of the actual timing. As in the other experiments, the 48-h lead time CTL underestimated the rainfall (even much lower than its counterpart of 72-h lead time run). VARALL with 48-h lead time simulated the rainfall event in two spells with two hours gap, with the amount and time of occurrence very close to the observations. This experiment produced more realistic results for the 2011 rainfall event than the other simulations. For both rainfall events, CTL runs failed to accurately capture the timing as well as the intensity of the rainfall for all lead times whereas VARALL with 48-h lead time successfully reproduced most of the features of this event in better agreement with the observations.

\subsubsection{Quantitative Rainfall Error Verification from simulations}

The lack of reliable rainfall observations is a critical constraint on weather and climate studies over the Middle East region (Almazroui, 2011; Benestad et al., 2012). Only four rain gauge observations are available for each rainfall event. This meager number of rainfall data does not permit proper assessment of the quantitative skill of the model. Alternatively, we used radar rainfall observations to carry out multi-threshold rainfall analysis (shown in Table 3) of CTL and VARLL for the two rainfall events. Before presenting the comparative analysis of model rainfall 
with that of radar, the radar data is compared against the available rain gauge data for the two events (SFig.1). This plot shows that the radar rainfall data compares well with the station rainfall (number of observation used is eight as we considered two events) with a correlation of 0.99 , but with a negative bias of $-21 \mathrm{~mm}$.

For rainfall analysis, statistical indices used in Table3 are Threat Score (TS), Percent Correct (PC), Probability of Detection (POD) or Hit rate and False Alarm Ratio (FAR) (Joliffe and Stephenson, 2003; Wilks, 2006; Mahringer, 2008). TS measures the fraction of forecast events that are correctly predicted, but it does not provide any information about the events that occur purely due to random chance. POD indicates the fraction of the observed hits and FAR evaluates the fraction of the predicted "yes" events that are not actually observed. PC is considered as the most important skill score for assessing the overall performance of the model, and it gives information about the total fraction of the correct forecasts in each category. In the present study, the rainfall amount is divided into six categories, namely No Rain (NR), Very Light Rain (VLR), Light Rain (LR), Moderate Rain (MR), Heavy Rain (HR), and Very Heavy Rain (VHR), with rainfall ranges as $0,0.1$ to $2.4,2.5$ to $7.5,7.5$ to $35.5,35.6$ to 64.4 and 64.5 to $144 \mathrm{~mm}$, respectively.

In general all the indices (TS, PC, POD, FAR) show comparatively higher values for VARALL than CTL for the different rainfall categories and over different lead times. The computed threat scores indicate that VARALL produced relatively higher threat scores for all categories of rainfall as compared to the CTL run. The better performance of VARALL in capturing the rainfall events is particularly evident from the large threat score values found around the timing of the heavy rainfall events (Table 3). The threat scores for both the heavy rainfall events for moderate to very heavy rainfall categories obtained with VARALL are roughly $20 \%$ higher than 
those obtained with CTL. For most of the rainfall categories, the POD scores computed for VARALL have increased from 96 to 48 hour lead time, and are found to be $10-15 \%$ higher than the corresponding CTL scores. The PC scores remained nearly steady for different lead time runs in both CTL and VARALL, however, the values obtained with VARALL are $10 \%$ higher than the corresponding scores of CTL for light to very heavy rainfall categories. Unlike the other three skill scores, false alarm ratios for VARALL with 96 and 72 hours lead time are 5\% higher than CTL for light rain to heavy rain categories, indicating a slight over prediction of the extent of rainfall. Thus, considering both the temporal rainfall evolution and the quantitative rainfall, VARALL simulated the rainfall associated with the two severe weather episodes over Jeddah more realistically than the control run. This substantiates the result that the assimilation of all available observations provides the best approach for predicting the heavy rainfall events.

\section{Summary and Conclusions}

This study investigated the impact of assimilation of available observational data for predicting heavy rainfall events that occurred over the city of Jeddah, Saudi Arabia. The results demonstrate the positive impact of assimilation using the WRF ARW model. To examine the impact of individual sources of observations on the simulation of the heavy rainfall events, six experiments (including the control run, CTL) were conducted by assimilating individual types of observations and their results were compared with an experiment assimilating all available observations (VARALL).To represent the model forecast errors during the winter, we have used static homogeneous BE for the study domain configuration which is generated using NMC method by considering a month long simulations of WRF during December 2008. Though the static BE can represent forecast errors to certain extent, it may underestimate the data impact due to deficiencies in flow independency (Buehner, 2005). For the future assimilation works we will

This article is protected by copyright. All rights reserved. 
use the flow dependent and inhomogeneous BE obtained from advanced hybrid assimilation techniques (Wang et al., 2008; Wang et al., 2014) which can further minimize the forecast uncertainties. Assimilation of all observations significantly reduced the errors in the model initial conditions. Regarding the individual observational sources, the surface observations improved the surface temperature, and the atmospheric motion vectors reduced the errors in the wind, particularly the meridional component. The profile observations (i.e., radiosondes and pilot balloon) enhanced the initial 3D-fields of meridional winds and moisture. The assimilation of radiance data caused major changes in the model thermo-dynamical fields mainly due to decreases in temperature and increments in relative humidity over Jeddah. These in turn modified the spatial pressure distribution and resulted in the formation of a low pressure over the northern Red Sea, strengthening the northerly wind over the eastern part of Egypt.

Analysis of the time evolution of surface parameters indicated faster dynamics and evolution of the storm in CTL by about two to three hours prior to the actual one. VARALL reproduced the timing of the drop and the rise in temperature in good agreement with the observations. Although the variation in temperature was very well simulated by VARALL during the storm hours, it overestimated the relative humidity changes. VARPRO provided the next best result, suggesting an important impact of profile observations on the simulation of heavy rainfall. The time series of the simulated thermodynamic fields also suggests the occurrence of a thunderstorm in the CTL simulation two to three hours earlier than the assimilation runs. Comparative analysis of the simulated reflectivity plots with PME radar imagery suggested that the convective storm moved relatively faster in CTL while it remained quasi-stationary in VARALL, as observed by the PME Radar. The strength of the storm is also found to be stronger in VARALL, consistent with the radar observations and is reflected in the amount of rainfall simulated over Jeddah. The stronger 
convergence of wind at $850 \mathrm{hPa}$ and divergence at $300 \mathrm{hPa}$ also indicate slow movement of the storm (quasi-stationary), during 0600 to 0800 UTC on 25 November 2009 resulting in more rainfall in VARALL than in CTL. The results of the rainfall comparisons indicate that the assimilation of all observations produced a higher amount of rain and a broader convective area over Jeddah.

To test the predictive skill of the WRF model for the two heavy rainfall events, we conducted three numerical experiments with simulation periods of $96 \mathrm{~h}, 72 \mathrm{~h}$, and $48 \mathrm{~h}$ for each event. The results indicate that WRF successfully captured the signature of convective storm events even three days in advance. With assimilation of all observations (VARALL), the strength of the storm as well as the distribution and amount of simulated rainfall are considerably improved. Results indicated that the 48-h lead time experiments with VARALL provided better rainfall simulations both in quantity and timing compared to the experiments with $72 \mathrm{~h}$ and $96 \mathrm{~h}$ lead times. Various statistical indices (TS, PC, POD, FAR) showed comparatively higher values for VARALL than CTL especially for moderate and higher rainfall categories with 48-h lead time. The improved statistical skill scores for the moderate and heavy rainfall categories obtained with VAR runs suggests that assimilation of the data is essential to achieve the best results for simulating the heavy rainfall events over Jeddah.

The observed and simulated thermo-dynamical indices of CAPE, K and TT show the basic features of a well-developed storm. The accumulation of CAPE from minimum to maxima suggests a possible occurrence of a storm, sustainment of CAPE maxima for few hours indicates the maturing stage of the storm, and sudden decrease of CAPE value indicates the cloud burst of the rainfall. The cloudburst of the storm occurs 2-3 hours before in CTL experiment than the 
observations and all conducted experiments demonstrate the relevance of the adopted assimilation method for storm prediction.

Our results suggest that WRF is capable of simulating heavy rainfall signatures and exhibits better skill and more precision in the time of occurrence with the assimilation of observations. One of the important results of this study is that the assimilation of all available observations helps to reproduce a more realistic picture and movement of the convective system, in the two events of heavy rainfall that occurred over Jeddah. The study clearly demonstrates that the combination of all observations reduces the biases found in both the control and the individual data assimilation experiments, leading to more accurate forecasts of the storm for the two heavy rainfall events that were simulated. Since the region of this study falls in an arid climate where the frequency of heavy rainfall events is very low, we considered two available potential events alone for our experiments. Although this is a sample to draw a general conclusion, our results suggest that assimilation of available conventional data (surface and upper air sounding observations) along with satellite radiances in mesoscale atmospheric models can help in predicting more realistically convective rainfall events in the data sparse and arid regions like Jeddah. The greater influence of the conventional data over satellite radiances found in the study suggest that a design of future observing system should consider with increase data density of conventional. The present simulations were based on four assimilation cycles for improving the initial fields, and may need further experiments for tuning and optimization. More case studies are also required to develop the prediction strategy of mesoscale convective rainfall events over the study region.

\section{Acknowledgments}

This article is protected by copyright. All rights reserved. 
This work was funded by King Abdullah University of Science and Technology (KAUST), Thuwal, Saudi Arabia. The authors would like to thank the Presidency of Meteorology and Environment (PME), Jeddah for providing synoptic charts, radar and satellite pictures for the analysis. The authors also thankful to Saudi Aramco for providing rainfall data .The WRF-ARW model is downloaded from University Corporation for Atmospheric Research (UCAR). The NCEP GFS $0.5^{\circ} \times 0.5^{\circ}$ analysis and its respective forecasts are obtained from NCEP NOMADS Server (http://nomads.ncdc.noaa.gov) and prepbufr global observational dataset, AMSU-A and AMSU-B satellite radiances are obtained from http://rda.ucar.edu. The TRMM rainfall estimates are downloaded from TRMM NASA GFSC server. The authors are grateful to the anonymous reviewers, whose constructive comments greatly improved the manuscript.

\section{References}

Al-Khalaf AK, Basset HA. 2013. Diagnostic study of a severe thunderstorm over Jeddah. Atmospheric and Climate Sciences, 3:150-164.

Almazroui M. 2011a. Sensitivity of a regional climate model on the simulation of high intensity rainfall events over the Arabian Peninsula and around Jeddah (Saudi Arabia). Theor. Appl. Climatol., 104:261-276

Almazroui M. 2011b. Calibration of TRMM rainfall climatology over Saudi Arabia during 19982009, Atmospheric Research, 99:400-414.

Almazroui M. 2012. The life cycle of extreme rainfall events over western Saudi Arabia simulated by a regional climate model: Case study of November 1996.Atmósfera, 25(1): 23-41.

Almazroui, M. 2013. Simulation of present and future climate of Saudi Arabia using a regional climate model (PRECIS). Int. J. Climatol., 33: 2247-2259. doi: 10.1002/joc.3721

Anderson SR, Graham, RJ, Bader MJ. 2000. The impact of observations on mesoscale model forecasts of three-hourly rainfall accumulations. Met.Apps., 7: 193-203.

Barker D, and coauthors 2012. The Weather Research and Forecasting Model's Community Variational/Ensemble Data Assimilation System: WRFDA. Bull. Amer. Meteor. Soc., 93:831843.

This article is protected by copyright. All rights reserved. 
Barker D, Lee MS, Guo YR, Huang W, HuangH, Kuo YH, Rizvi S, Xiao Q, 2005.WRF-VarA unified 3/4DVAR variational data assimilation system for WRF. Sixth WRF/15th MM5 Users' Workshop, Boulder, CO, NCAR, pp 17.

Barker DM, Huang W, Guo YR, Xiao QN. 2004. A three dimensional (3DVAR) data assimilation system for use with MM5: implementation and initial results. Mon Wea.Rev., 132:897-914

Benestad RE, Nychka D, Mearns LO. 2012. Spatially and temporally consistent prediction of heavy precipitation from mean values. Nature Climate Change. 2:544-547.

Bradley T Zavodsky, Shih-Hung Chou, Gary JJedlovec. 2012. Improved regional analyses and heavy precipitation forecasts with assimilation of atmospheric infrared sounder retrieved thermodynamic profiles. IEEE Transactions On Geoscience And Remote Sensing. 50 (11): 42434251 .

Chen F, Dudhia J. 2001. Coupling an advanced land-surface/hydrology model with the Penn State/NCAR MM5 modeling system. Part I: Model description and implementation. Mon. Wea. Rev. 129:569-585.

Chen, Shu-Hua, Zhan Zhao, Jennifer S. Haase, Aidong Chen, Francois Vandenberghe. 2008. A study of the characteristics and assimilation of retrieved MODIS total precipitable water data in severe weather simulations. Mon. Wea. Rev. 136:3608-3628.

Cherubini T, Businger S, Velden C, Ogasawara R. 2006. The impact of satellite-derived atmospheric motion vectors on mesoscale forecasts over Hawaii. Mon. Wea. Rev., 134:20092020. doi: http://dx.doi.org/10.1175/MWR3163.1

Colle BA, Mass CF. 2000. High-resolution observations and numerical simulations of easterly gap flow through the Strait of Juan de Fuca on 9-10 December 1995. Mon. Wea. Rev., 128:2398-2422.

Courtier P, Andersson E, Heckley W, Pailleux J, Vasiljevic D, Hamrud M, Hollingsworth A, Rabier F, Fisher M. 1998. The ECMWF implementation of three dimensional variational assimilation (3D-Var). I: Formulation. Q. J. R. Meteorol. Soc., 124:1783-1807.

De Vries AJ, Tyrlis E, Edry D, Krichak SO, Steil B, Lelieveld J. 2013. Extreme precipitation events in the Middle East: Dynamics of the Active Red Sea Trough, J. Geophys. Res. Atmos., 118:7087-7108, doi:10.1002/jgrd.50569.

Deng L, McCabe MF, Stenchikov GL, Evans JP, Kucera PA. 2013. High resolution simulation and forecasting of Jeddah floods using WRF version 3.5, Abstract H41E-1264 presented at 2013 Fall Meeting, AGU, San Francisco, Calif., 9-13 Dec.

This article is protected by copyright. All rights reserved. 
Deng L, McCabe FM, Georgiy Stenchikov, Evans JP, Kucera PA, 2015. Simulation of FlashFlood-Producing Storm Events in Saudi Arabia Using the Weather Research and Forecasting Model. J. Hydrometeor, 16, 615-630.

Derber JC, Wu WS. 1998. The use of TOVS cloud-cleared radiances in the NCEP SSI analysis system. Mon. Wea. Rev., 126:2287-2299.

Dinku T, Connor SJ, Ceccato P. 2010. Comparison of CMORPH and TRMM-3B42 over Mountainous regions of Africa and South America, Satellite Rainfall Applications for Surface Hydrology., pp. 193-204, Springer Netherlands, Dordrecht, doi:10.1007/978-90-481-2915-7_11.

Dinku T, Emmanouil N Anagnostou. 2006. TRMM calibration of SSM/I algorithm for overland rainfall estimation. J. Appl. Meteor. Climatol. 45, 875-886.

English SJ, Renshaw RJ, Dibben PC, Smith AJ, Rayer PJ, Poulsen C, Saunders FW, Eyre JR. 2000. A comparison of the impact of TOVS and ATOVS satellite sounding data on the accuracy of numerical weather forecasts. Q. J. R. Meteorol. Soc., 126, 2911-2931.

Faccani C, Ferretti R. 2005. Data assimilation of high-density observations. I: Impact on initial conditions for the MAP/SOP IOP2b. Q.J.R. Meteorol. Soc., 131: 21-42. doi: 10.1256/qj.03.56A.

Greeshma MM, Srinivas CV, Yesubabu V, Naidu CV, Baskaran R, Venkatraman B. 2015. Impact of local data assimilation on tropical cyclone predictions over the Bay of Bengal using the ARW model. Ann. Geophys., 33, 805-828. doi:10.5194/angeo-33-805-2015.

Habib EH, Nasrollahi N. 2009. Evaluation of TRMM-TMPA satellite rainfall estimates over arid regions. American Geophysical Union., Fall Meeting 2009, abstract \#H12A-02, San Francisco, 2009.

Haggag M, El-Badry H. 2013. Mesoscale numerical study of quasi-stationary convective system over Jeddah in November 2009. Atmospheric and Climate Sciences, 3, 1:73-86. doi: $10.4236 / \operatorname{acs} .2013 .31010$

Huang X-Y, Xiao Q, Barker DM, Zhang X, Michalakes J, Huang W, Henderson T, Bray J, Chen Y, Ma Z, Dudhia J, Guo Y, Zhang X,. WonD-J, LinHC, Kuo YH. 2009. Four-Dimensional Variational Data Assimilation for WRF: Formulation and Preliminary Results. Mon. Wea. Rev., 137, 299-314.

Hong SY, Noh Y, Dudhia J. 2006. A new vertical diffusion package with explicit treatment of entrainment processes. Mon. Wea. Rev., 134:2318-2341.

Hsiao, L-F, Chen D-S, Kuo Y-H,Guo Y-R, Yeh T-C, Hong J-S, Fong C-T, Lee C-S, 2012. Application of WRF 3DVAR to Operational Typhoon Prediction in Taiwan: Impact of Outer Loop and Partial Cycling Approaches. Wea. Forecasting, 27, 1249-1263.

This article is protected by copyright. All rights reserved. 
Ide K, Courtier P, Ghil M, Lorenc AC. 1997. Unified notation for data assimilation: operational, sequential and variational. J. Met. Soc. Jpn., 75, 181-189.

Jiang H, Farrar JT, Beardsley RC, Chen R, Chen C. 2009. Zonal surface wind jets across the Red Sea due to mountain gap forcing along both sides of the Red Sea. Geophys. Res. Lett., 36, L19605, doi:10.1029/2009GL040008, 2009.

Joyce RJ, Janowiak JE, Arkin PA, Xie P. 2004. CMORPH: a method that produces global precipitation estimates from passive microwave and infrared data at high spatial and temporal resolution. J. Hydrometeorol., 5:487-503

Kahana R, Ziv B, Dayan U, Enzel Y. 2004. Atmospheric predictors for major floods in the Negev desert, Israel, Int. J. Climatol., 24(9), 1137-1147, doi:10.1002/joc.1056.

Kahana R, Ziv B, Enzel Y, Dayan U. 2002. Synoptic climatology of major floods in the Negev Desert, Israel. Int. J. Climatology 22: 867-822.

Kain JS, Fritsch JM. 1993. Convective parameterization for mesoscale models: the Kain-Fritcsh scheme. In: KA Emanuel, DJ Raymond (eds) The representation of cumulus convection in numerical models. American Meteorological Society, USA, p 246.

Kalnay E. 2003. Atmospheric modeling, data assimilation and predictability. Published Cambridge University Press, pp. 364

Katibah M. 2012. Impact of flood disaster on the mental health of residents in the eastern region of Jeddah governorate, A Study in Medical geography. Life Science Journal, 9(1):95-110, ISSN: 1097-8135.

Liu Z, Schwartz CS, Snyder C, Ha SY (2012) Impact of assimilating AMSU-A radiances on forecasts of 2008 Atlantic tropical cyclones initialized with a limited-area ensemble Kalman filter. Mon Weather Rev 140:4017-4034

Köppen W. 1936. Das geographisca System der Klimate, in: Handbuch der Klimatologie, edited by: Köppen, W. and Geiger, G., Borntraeger, 1-44.

Krichak SO, Breitgand JS, Feldstein SB, 2012.A conceptual model for the identification of the Active Red Sea Trough Synoptic events over the southeastern Mediterranean.J. App. Meteorol. Climatol., 51(5), 962-971, doi:10.1175/JAMC-D-11-0223.1.

Lee DK, Kim HR, Hong SY, 1998. Heavy rainfall over Korea during 1980-1990. Korean J. of Atmos., 1, 32-50.

Liu ZQ and Rabier F. 2003. The potential of high-density observations for numerical weather prediction: A study with simulated observations. Q. J. R. Meteorol. Soc., 129(594).

This article is protected by copyright. All rights reserved. 
Liu Z-Q, Rabier F. 2002. The interaction between model resolution, observation resolution and observation density in data assimilation: A one dimensional study. Q. J. R. Meteorol. Soc. 128, $1367-1386$.

Lu WU, Zhai P. 2012. Validation of Daily Precipitation from Two High-Resolution Satellite Precipitation Datasets over the Tibetan Plateau and the Regions to Its Eas, Acta Meteor.Sinica. $26(6): 735-745$.

Liu Z, Schwartz CS, Snyder C, Ha SY 2012. Impact of assimilating AMSU-A radiances on forecasts of 2008 Atlantic tropical cyclones initialized with a limited-area ensemble Kalman filter. Mon Weather Rev 140:4017-4034.

Mass CF, Ovens D, Westrick K, Colle BA. 2002. Does increasing horizontal resolution produce more skillful forecasts. Bull. Am. Meteorol. Soc. 83:407-430.

McNally AP, Derber J C, Wu W-S, Katz BB. 2000. The use of TOVS level-1B radiances in the NCEP SSI analysis system. Q. J. R. Meteorol. Soc. 126, 689-724.

Mlawer EJ, Taubman SJ, Brown PD, Iacono MJ, Clough SA. 1997. Radiative transfer for inhomogeneous atmosphere: RRTM, a validated correlated-k model for the longwave. J. Geophys Res. 102(D14):16663-16682.

Navon IM. 2009. Data assimilation for numerical weather prediction: A review. In: Park, S.K. and $\mathrm{Xu}, \mathrm{L}$. (eds), Data assimilation for atmospheric, oceanic and hydrologic applications, Springer, Berlin.

Parrish DF, Derber JC. 1992. The National Meteorological Center's Spectral Statistical Interpolation analysis system. Mon. Wea. Rev., 120:1747-1763.

Pedgley DE, 1966.The Red Sea Convergence Zone. Weather, 21: 350-358. doi: 10.1002/j.14778696.1966.tb02776.x

Rakesh V, Singh R, Pal PK, Joshi PC 2009: Impacts of satellite-observed winds and total precipitable water on WRF short-range forecasts over the Indian region during the 2006 summer monsoon; Weather Forecast., 24 1706- 1731.

Routray A, Kar S, Mali P, Sowjanya K, 2014. Simulation of Monsoon Depressions using WRFVAR: Impact of Different Background Error Statistics and Lateral Boundary Conditions. Mon. Wea. Rev. doi:10.1175/MWR-D-13-00285.1, in press.

Ruggiero FH, Sashegyi KD, Madala RV, Raman S. 1996. The use of surface observations in four-dimensional data assimilation in a mesoscale model. Mon.Wea. Rev. 124:1018-1033.

Schwitalla T, Bauer H-S, Wulfmeyer V, Aoshima F. 2011. High-resolution simulation over central Europe: assimilation experiments during COPS IOP 9c. Q. J. R. Meteorol. Soc., 137: 156-175. doi:10.1002/qj.721.

This article is protected by copyright. All rights reserved. 
Shentsis I, Laronne JB, Alpert P, 2012. Red Sea Trough floods in the Negev, Israel (1964-2007), Hydrol. Sci. J., 57(1), 42-51, doi:10.1080/02626667.2011.636922.

Shwehdi MH. 2005. Thunderstorm distribution and frequency in Saudi Arabia, J. Geophys. Eng. 2:252-267, doi:10.1088/1742-2132/2/3/009

Sinkevich AA, Terrence WK. 2013. Changes in thunderstorm characteristics due to feeder cloud merging, Atmos. Resea., http://dx.doi.org/10.1016/j.atmosres.2013.06.007

Skamarock WC, Klemp JB, Dudhia J, Gill DO, Barker DM, Dudha MG, Huang X, Wang W, Powers Y. 2008. A description of the Advanced Research WRF Ver.30.NCAR Technical Note.NCAR/TN-475+STR. Mesocale and Microscale Meteorology Divison, National Centre for Atmospheric Research, Boulder Colorado, USA. pp 113.

Srinivas CV, Hariprasad D, BhaskarRao DV, Anjaneyulu Y, Baskaran R, Venkataraman B 2012.: Simulation of the Indian summer monsoon regional climate using advanced research WRF model. Int. J. Climatol., doi:10.1002/joc.3505.

Sun J, Wang H. 2013. Radar Data Assimilation with WRF 4D-Var. Part II: Comparison with 3DVar for a Squall Line over the U.S. Great Plains.Mon. Wea. Rev., 141, 2245-2264, doi: http://dx.doi.org/10.1175/MWR-D-12-00169.1

Tuanjie H, Fanyou K, Xunlai C, Hengchi L. 2013. Impact of 3DVAR data assimilation on the prediction of heavy rainfall over southern China. Advances in Meteorology, Article ID 129642, doi:10.1155/2013/129642.

Wang D, Liang X, Duan Y, Chan JCL. 2006. Impact of four-dimensional variational data assimilation of atmospheric motion vectors on tropical cyclone track forecasts. Weather. Forecast. 21:663-66

Wang X, Barker DM, Snyder C, Hamill TM, 2008.A Hybrid ETKF-3DVAR Data Assimilation Scheme for the WRF Model. Part I: Observing System Simulation Experiment. Mon. Wea. Rev., 136, 5116-5131.doi: http://dx.doi.org/10.1175/2008MWR2444.1

Wang H, Sun J, Zhang X, Huang X-Y, AulignéT. 2013. Radar Data Assimilation with WRF 4DVar. Part I: System Development and Preliminary Testing. Mon. Wea. Rev., 141, 2224-2244, doi: http://dx.doi.org/10.1175/MWR-D-12-00168.1

Weng F, HanY, van DelstP, LiuQ, Yan B, 2005. JCSDA community radiative transfer model (CRTM).paper presented at FourteenthInternational ATOVS Study Conference, Int. TOVS Working Group, Beijing.

Wang H, Huang X-Y, Sun J, Xu D, Zhang M, Fan S, Zhong J. 2014.Inhomogeneous Background Error Modeling for WRF-Var Using the NMC Method. J. Appl. Meteor. Climatol., 53, 22872309. doi: http://dx.doi.org/10.1175/JAMC-D-13-0281.1

This article is protected by copyright. All rights reserved. 
zoomed portion of the figure indicates the topography of the innermost domain and locations frequently referred in the study.
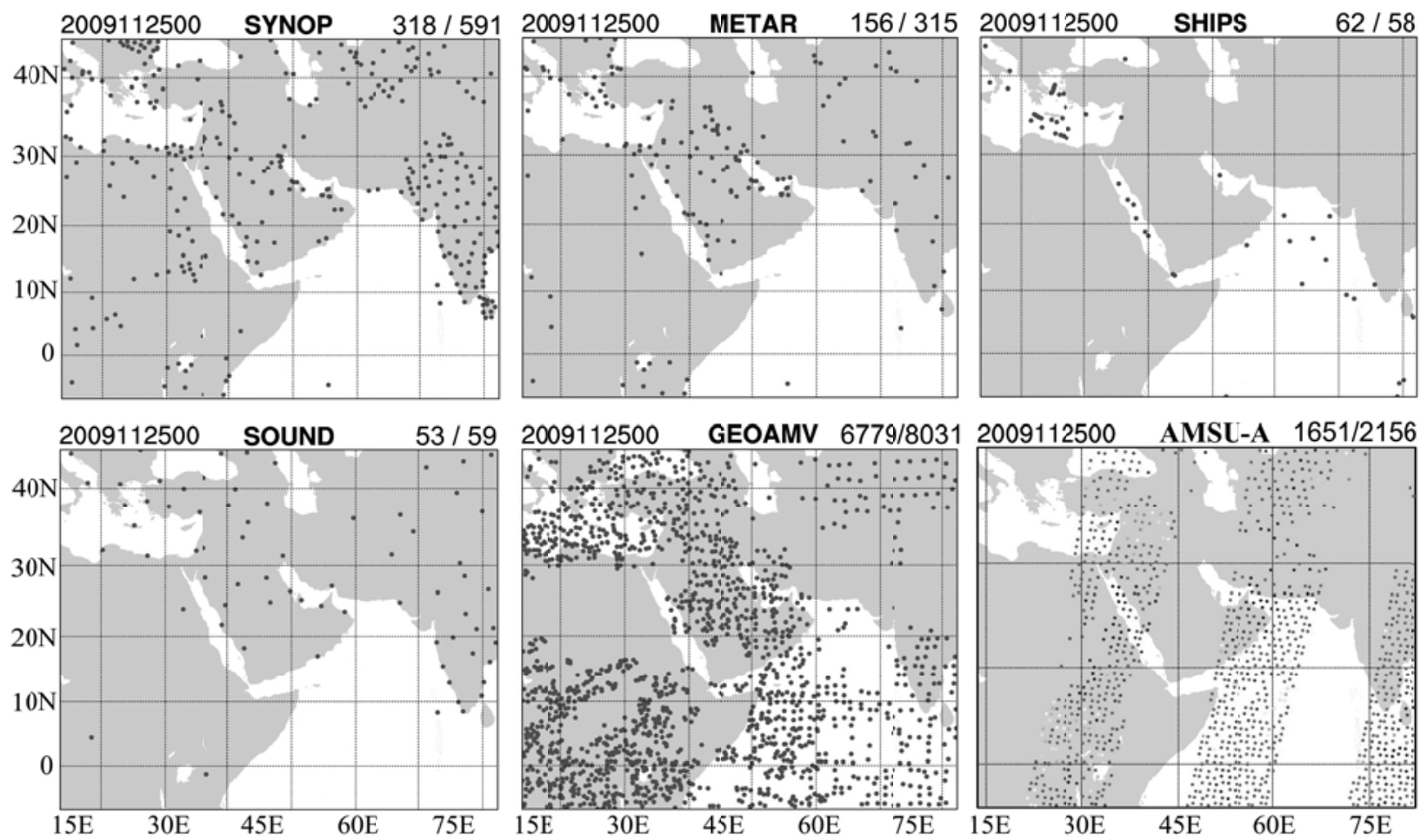

2) Spatial distribution of the observations that have been assimilated into the WRFDA system at 0000 UTC 24 November 2009. Number of observations assimilated in 3DVAR system to that of total observations available at the time of assimilation is indicated in the left corner of each plot.

This article is protected by copyright. All rights reserved. 

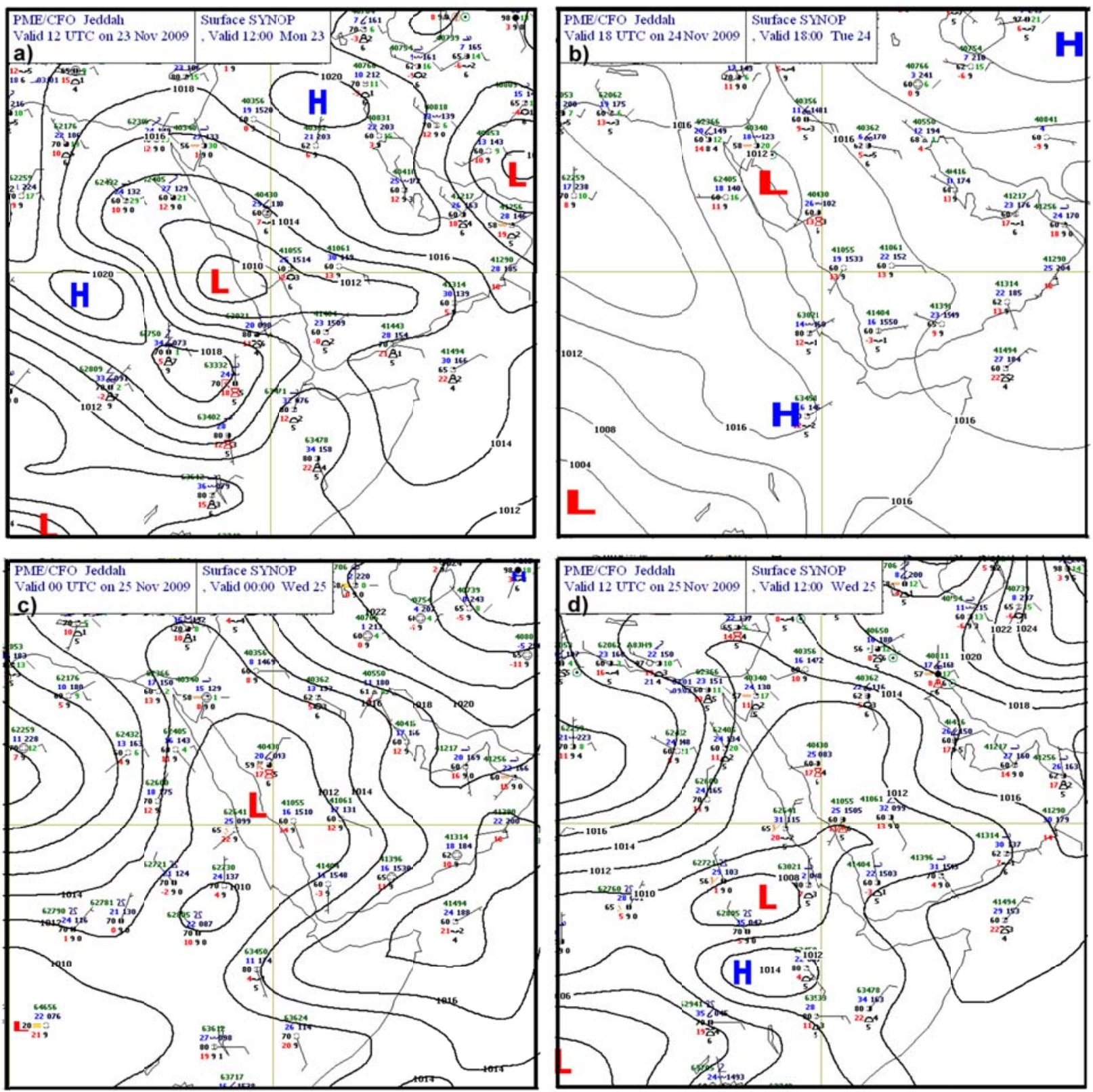

3) Surface synoptic chart from PME, Jeddah at a) 12 UTC 23, b) 18 UTC 24, c) 00 UTC, 25,and d) 12 UTC 25 November 2009. 

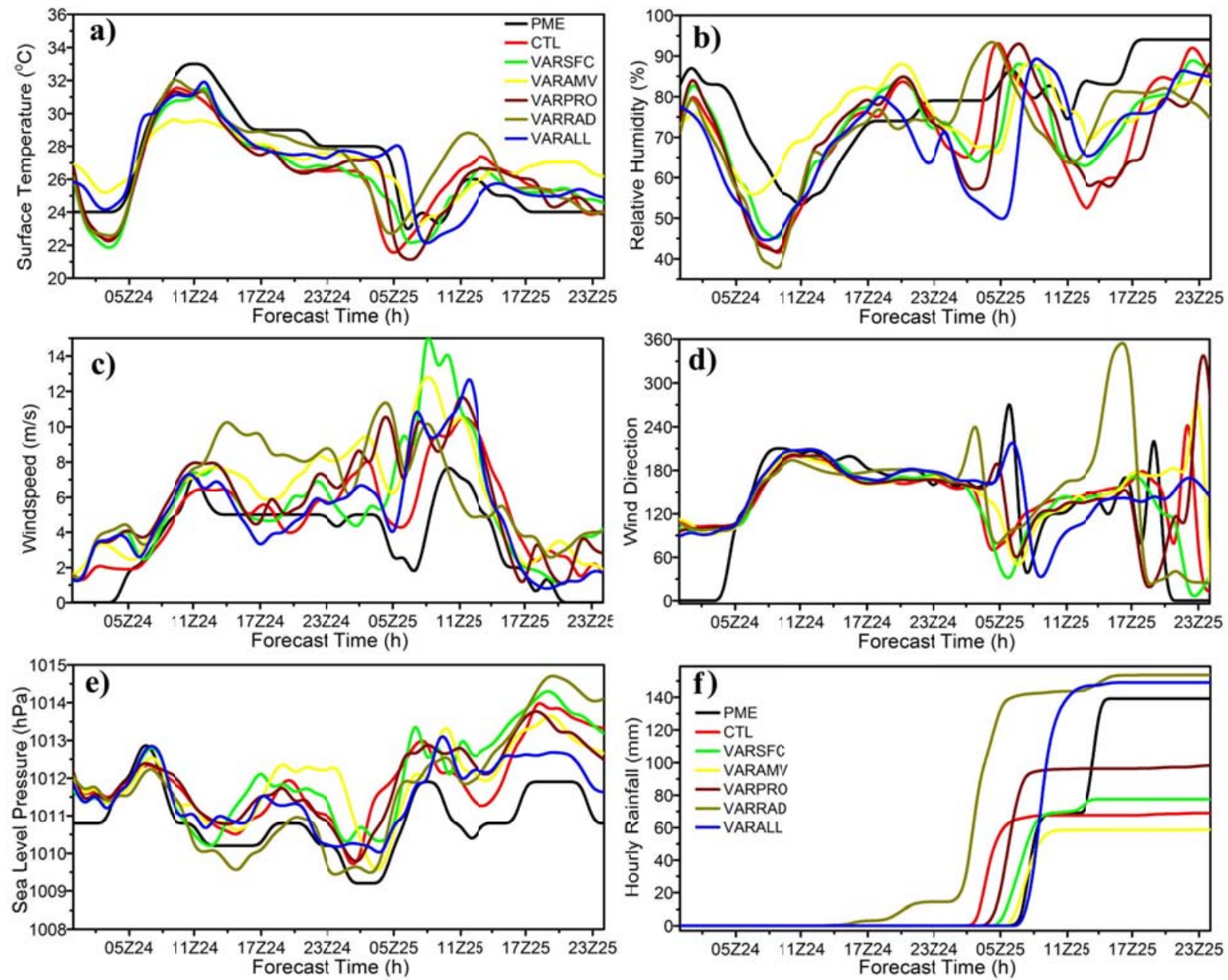

8) Time variation of simulated surface parameters versus the observations from PME surface synoptic station $\left(21.67^{\circ} \mathrm{N}, 39.15^{\circ} \mathrm{E}\right)$, Jeddah.

This article is protected by copyright. All rights reserved. 

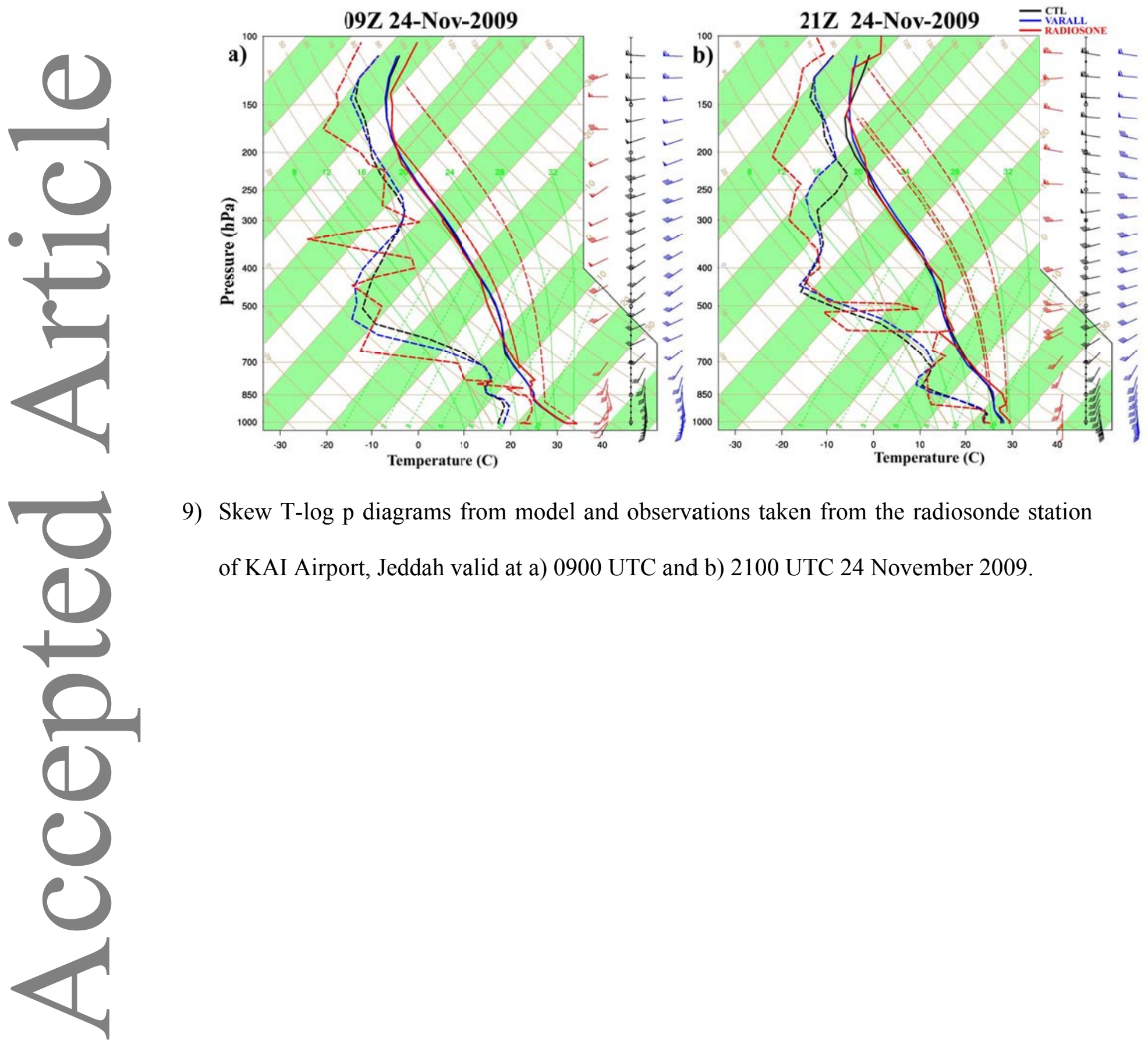

9) Skew T-log $\mathrm{p}$ diagrams from model and observations taken from the radiosonde station of KAI Airport, Jeddah valid at a) 0900 UTC and b) 2100 UTC 24 November 2009.

This article is protected by copyright. All rights reserved. 

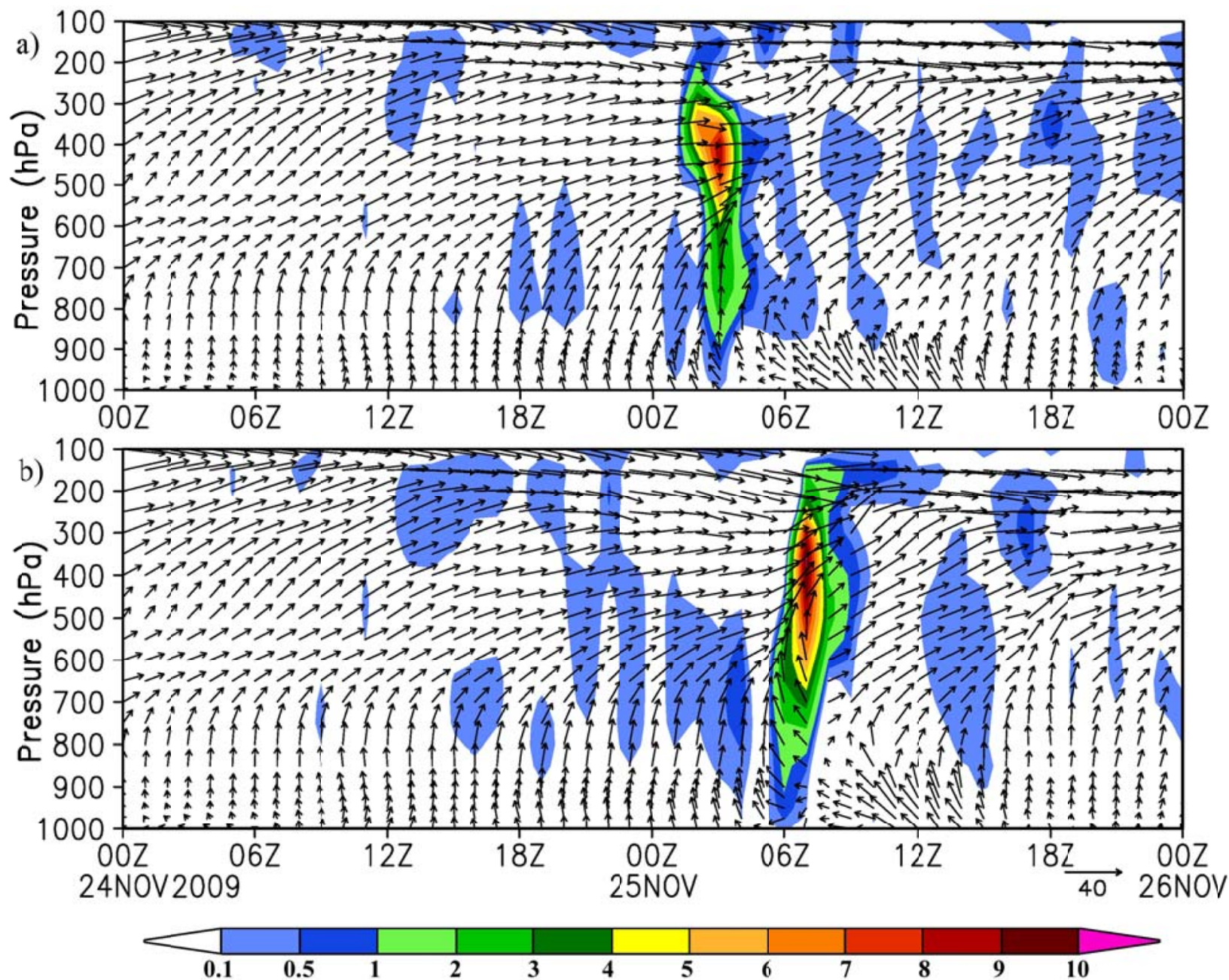

10) Time-height cross-section of horizontal (arrows) and vertical winds (shaded) from a)

CTL and b) VARALL at the radiosonde location of KAI Airport Jeddah $\left(21.6^{\circ} \mathrm{N}, 39.15^{\circ}\right.$

E). 

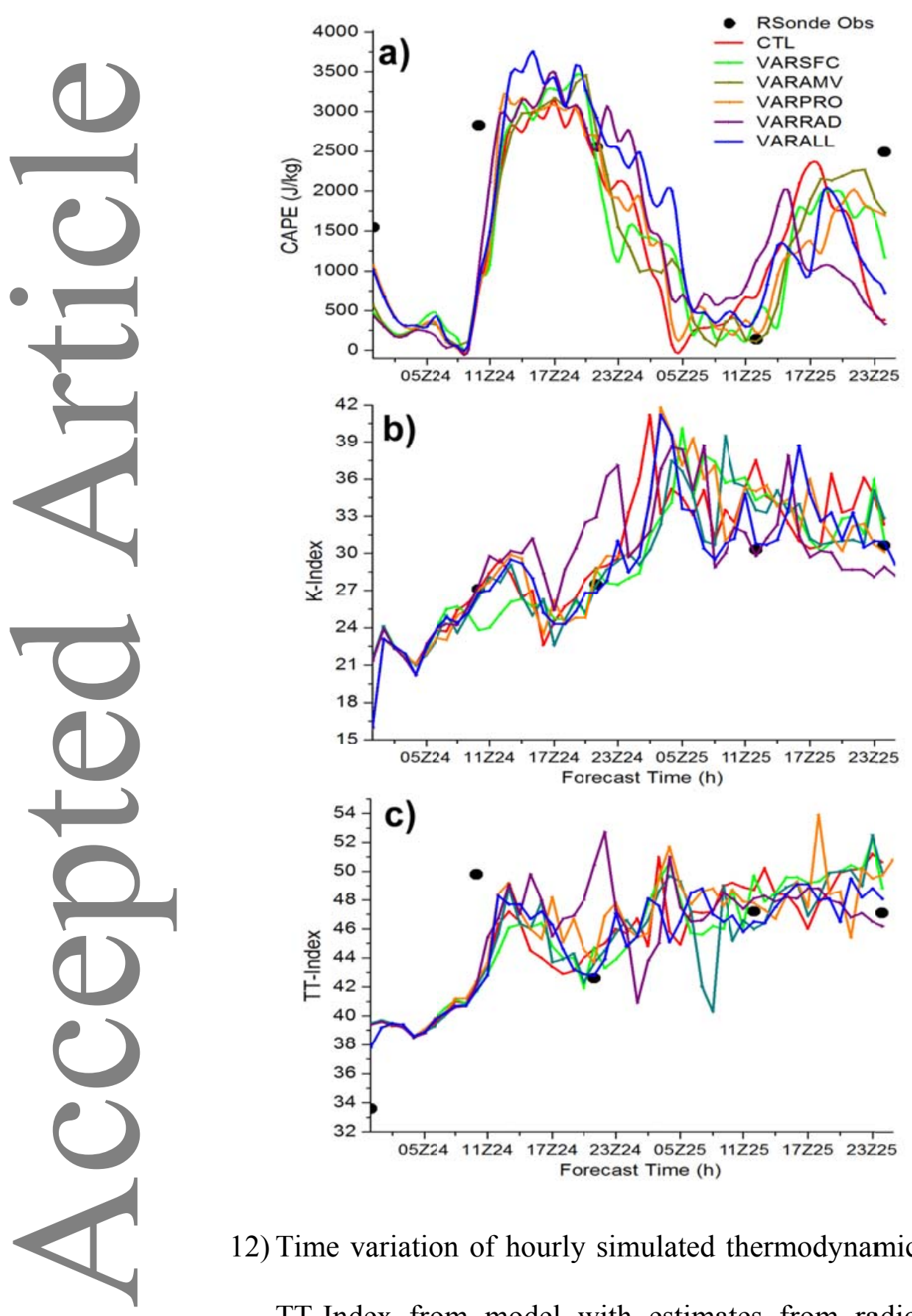

12) Time variation of hourly simulated thermodynamic parameters a) CAPE, b) K-Index c) TT-Index from model with estimates from radiosonde observations at KAI Airport location, Jeddah.

This article is protected by copyright. All rights reserved. 

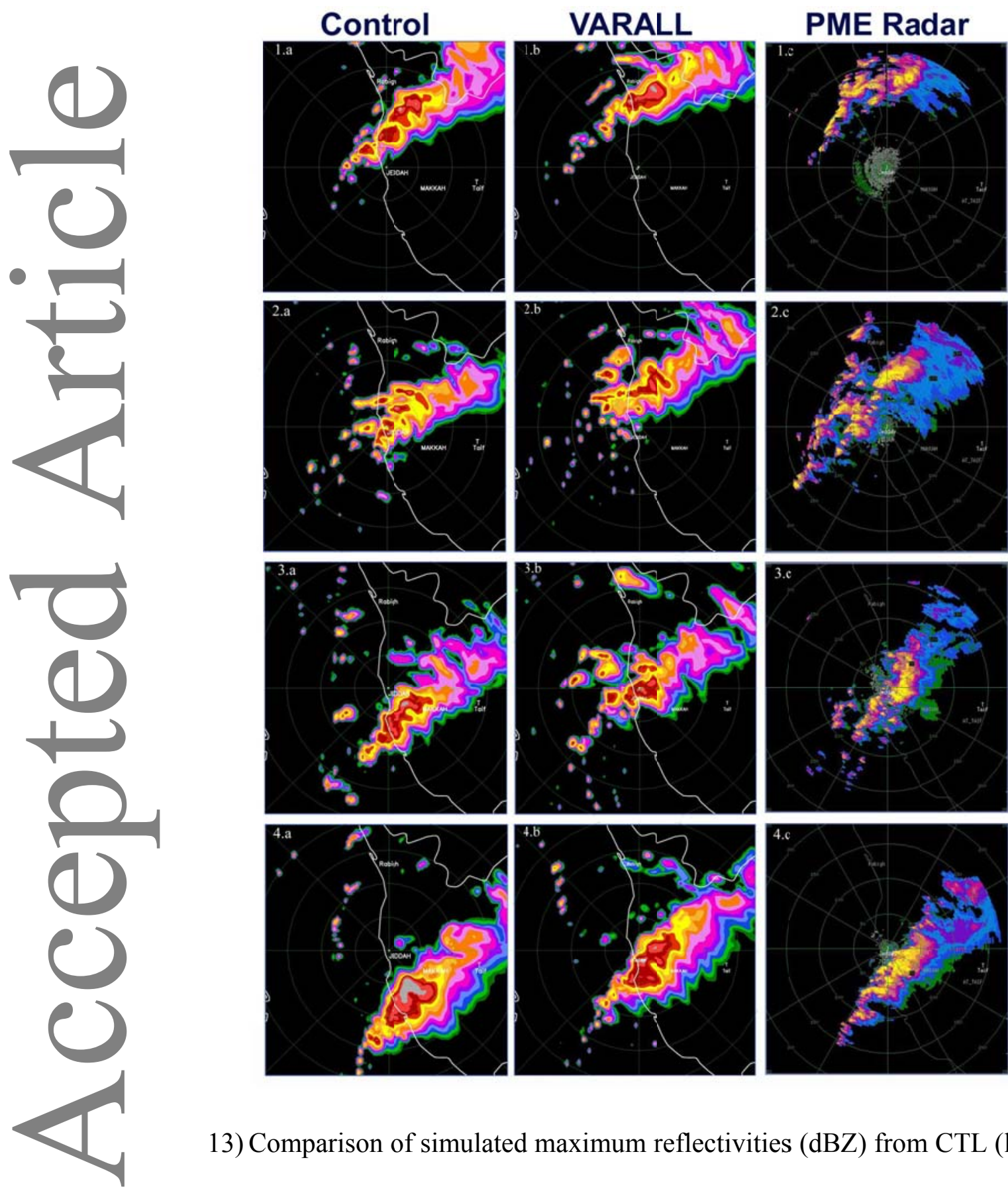

$00 Z 25$
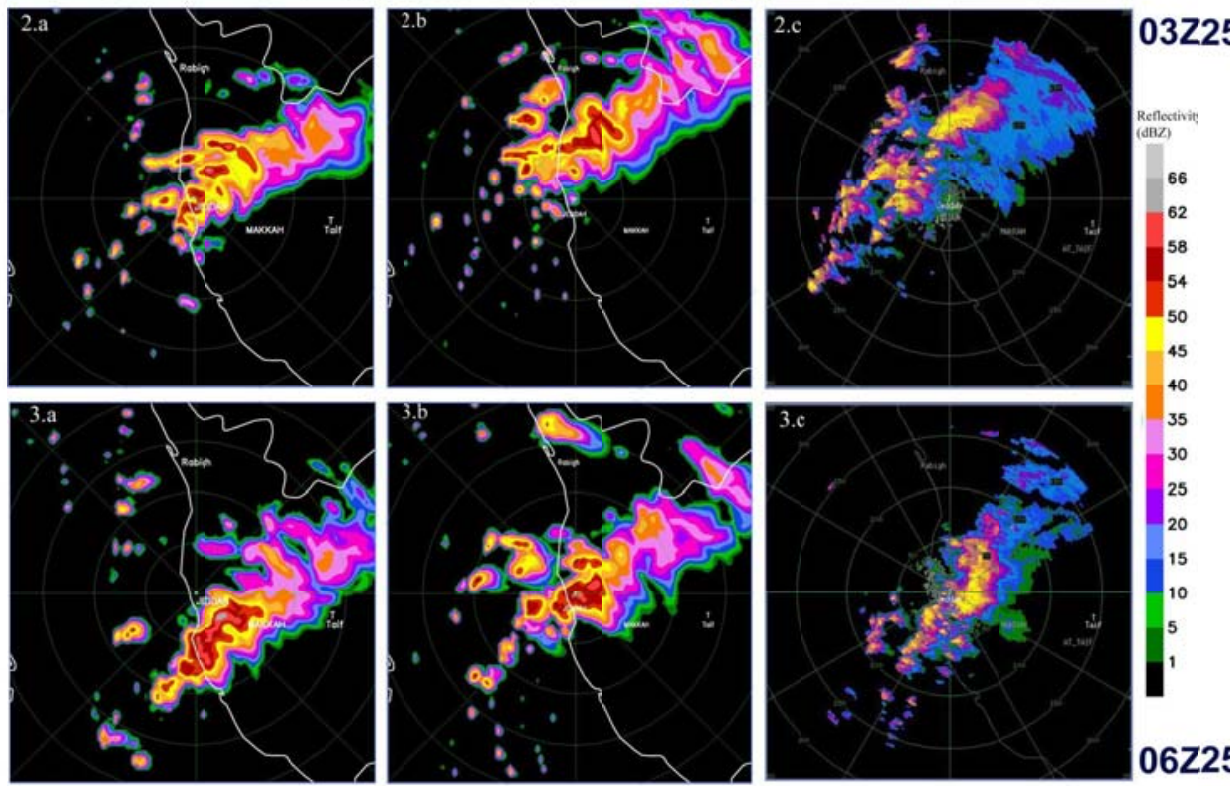

$03 Z 25$

Nov09
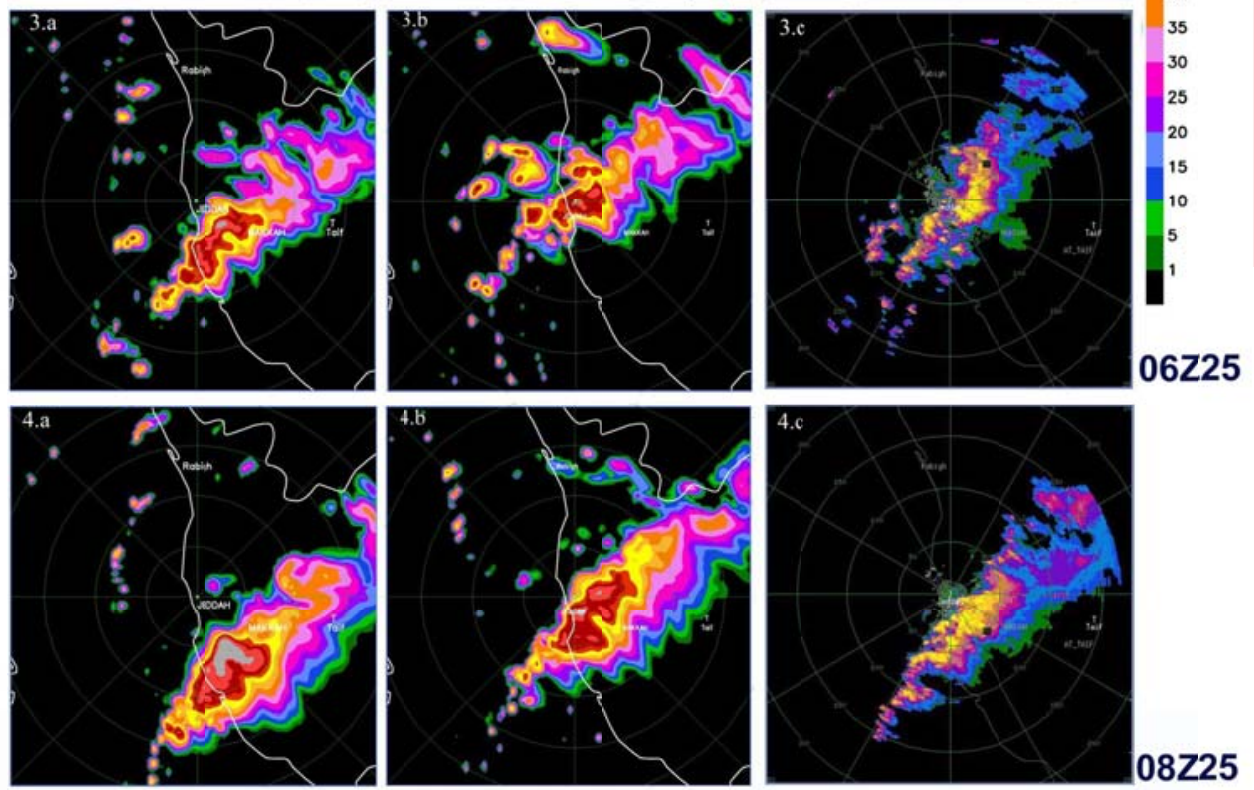

13) Comparison of simulated maximum reflectivities (dBZ) from CTL (left panel), VARALL (middle panels) with data from PME Radar images (right panels) valid at 12.1) 0000 UTC, 12.2) 0300 UTC, 12.3) 0600 UTC 12.4) 0800 UTC 25 November 2009. 

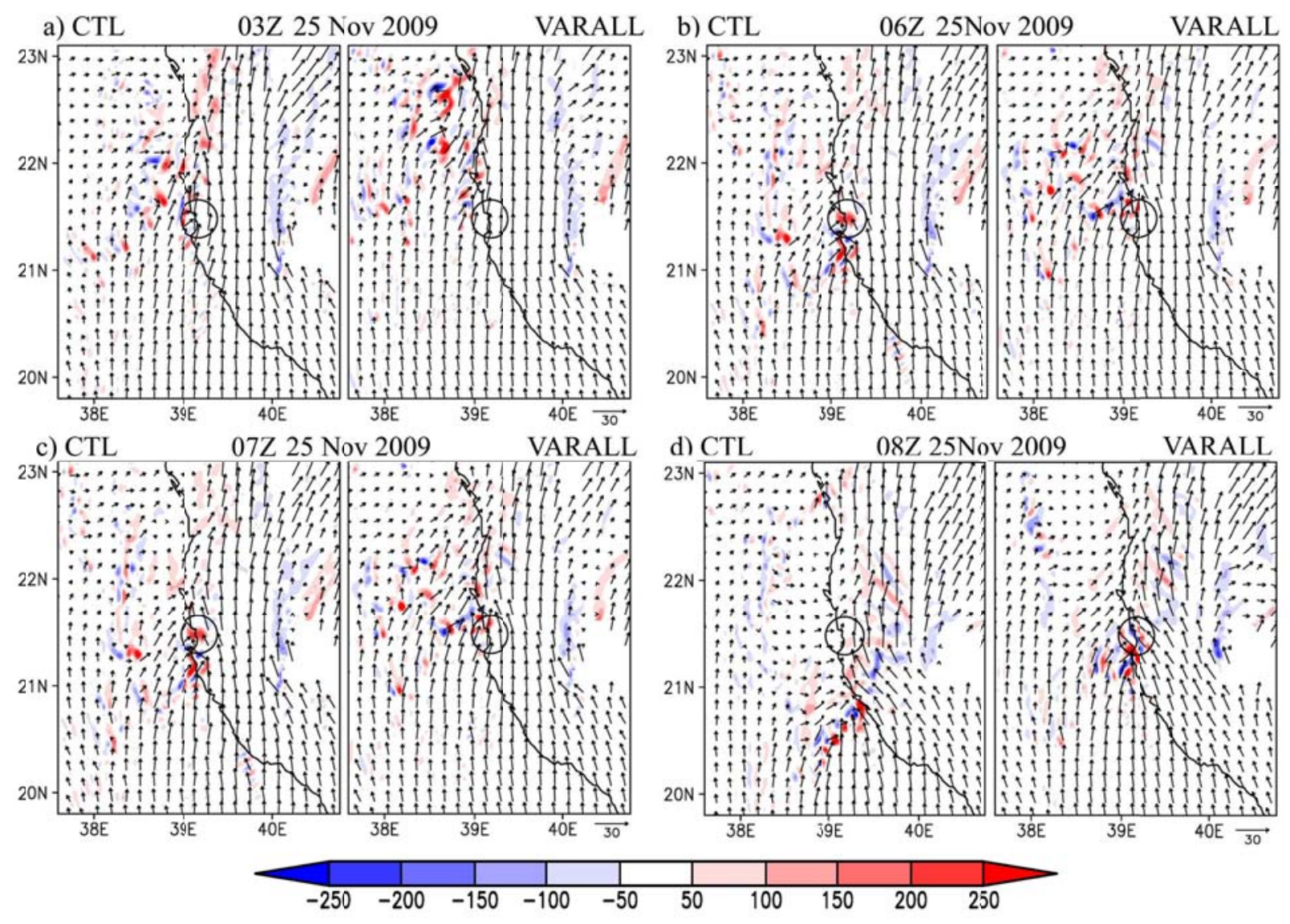

14) $850 \mathrm{hPa}$ winds (ms-1; vectors) and vorticity (10-6 s-1; shaded) from CTL (right panels) and VARALL (left panels) experiments valid at a) $0300 \mathrm{UTC}$, b) $0600 \mathrm{UTC}$, c) 0700 UTC and d) 0800 UTC 25 November 2009. Area confined in the black circle indicates the extent of Jeddah City. 

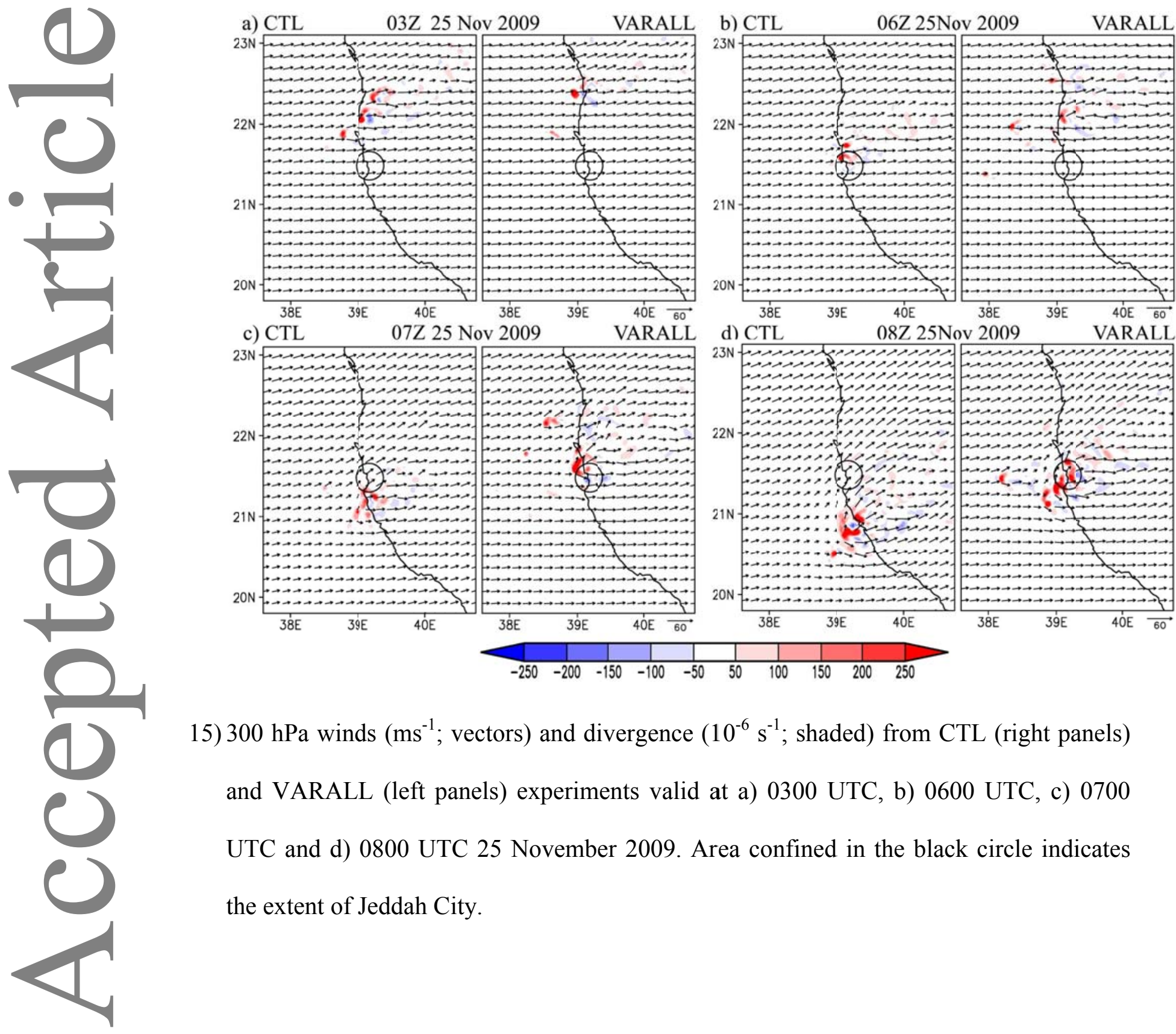

15) $300 \mathrm{hPa}$ winds ( $\mathrm{ms}^{-1}$; vectors) and divergence $\left(10^{-6} \mathrm{~s}^{-1}\right.$; shaded) from CTL (right panels) and VARALL (left panels) experiments valid at a) 0300 UTC, b) 0600 UTC, c) 0700 UTC and d) 0800 UTC 25 November 2009. Area confined in the black circle indicates the extent of Jeddah City.

This article is protected by copyright. All rights reserved. 

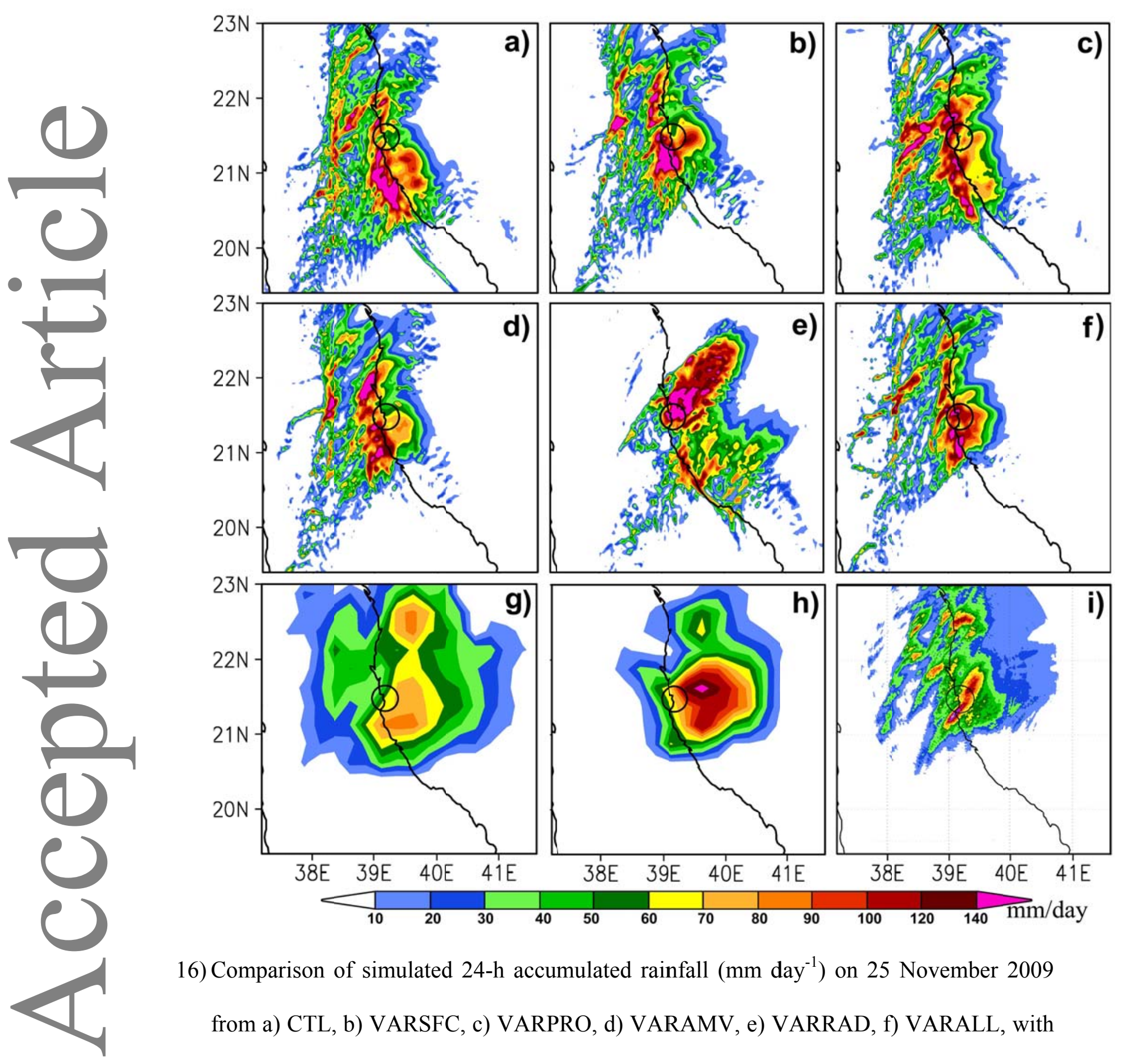

16) Comparison of simulated 24-h accumulated rainfall $\left(\mathrm{mm} \mathrm{day}^{-1}\right)$ on 25 November 2009

from a) CTL, b) VARSFC, c) VARPRO, d) VARAMV, e) VARRAD, f) VARALL, with observed rainfall estimates of g) TRMM 3B42V7, h) CMORPH and i) PME Radar. 

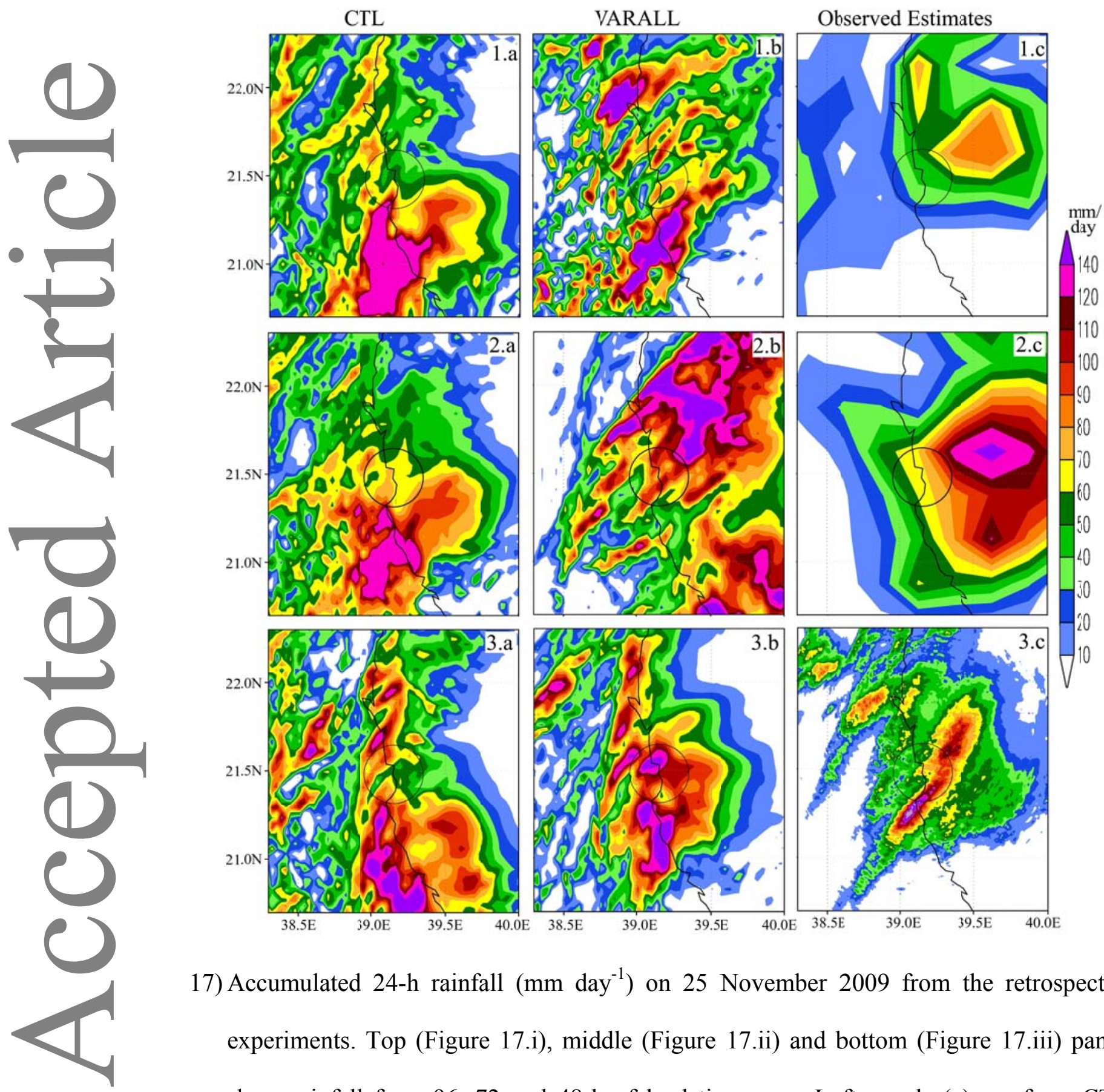

17) Accumulated 24-h rainfall $\left(\mathrm{mm} \mathrm{day}^{-1}\right)$ on 25 November 2009 from the retrospective experiments. Top (Figure 17.i), middle (Figure 17.ii) and bottom (Figure 17.iii) panels show rainfall from 96, 72 and 48-h of lead time runs. Left panels (a) are from CTL, middle panels (b) are from 3DVAR, and right panels (c) are from observations. 

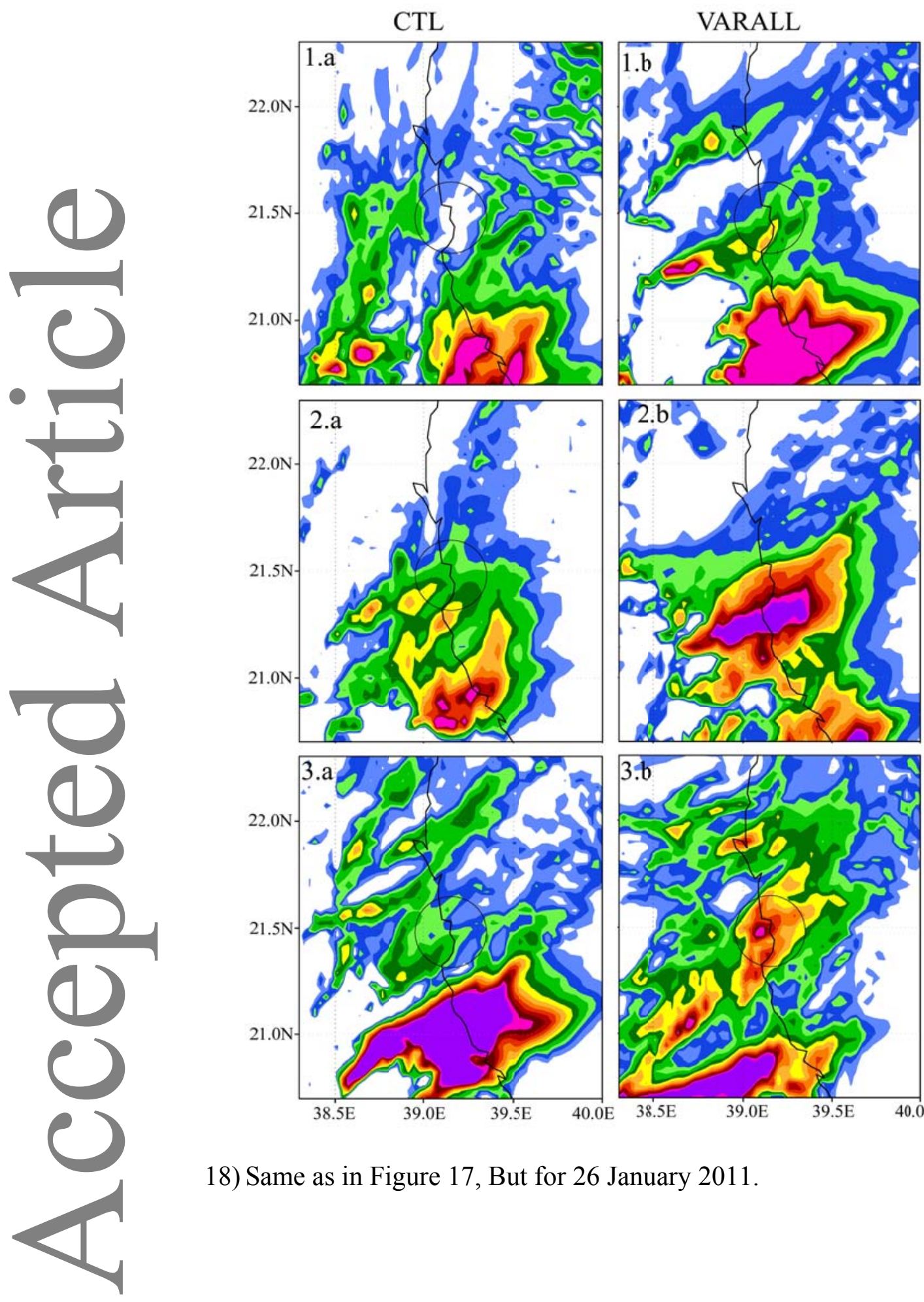

Observed Estimates
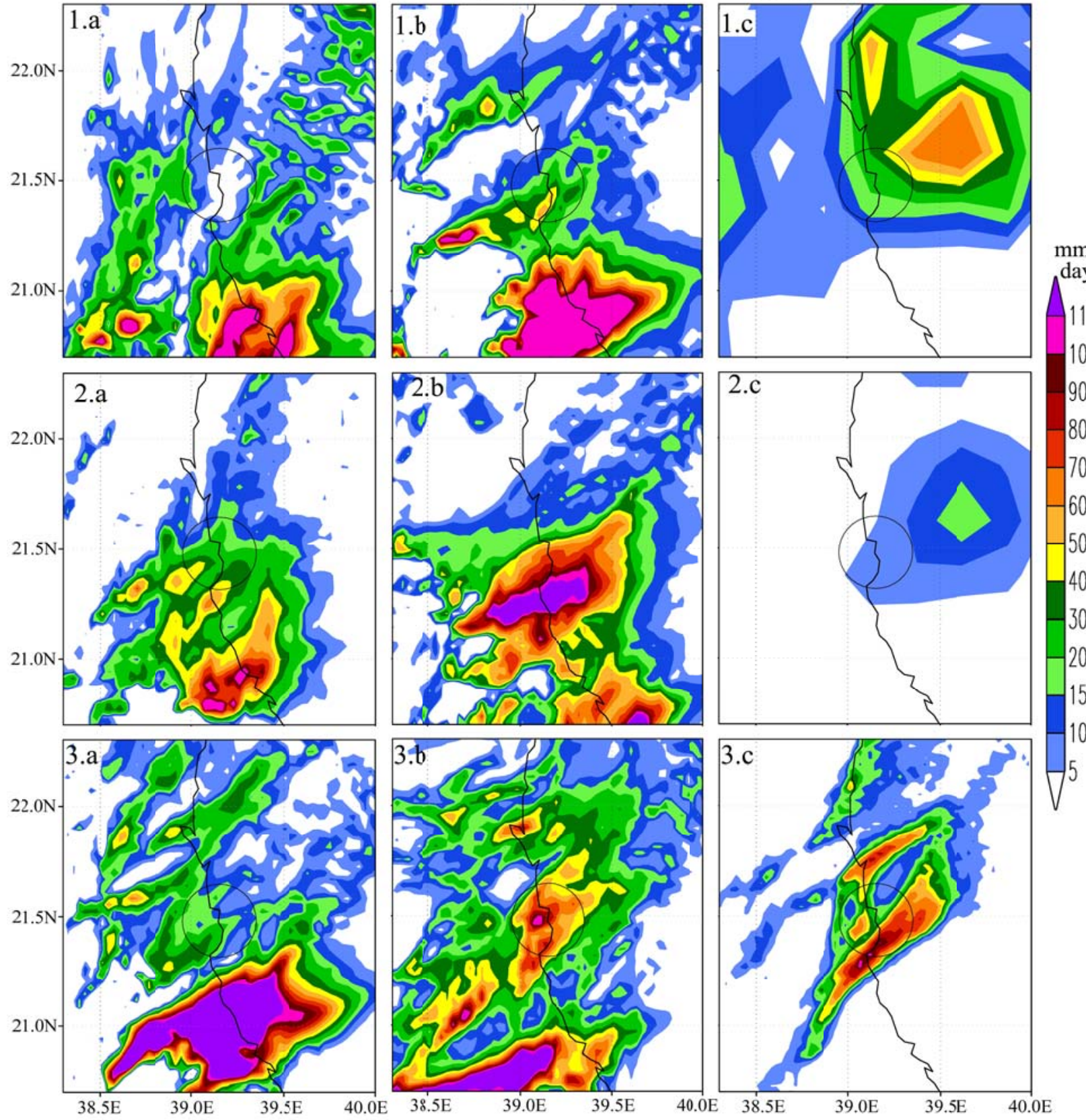

18) Same as in Figure 17, But for 26 January 2011. 

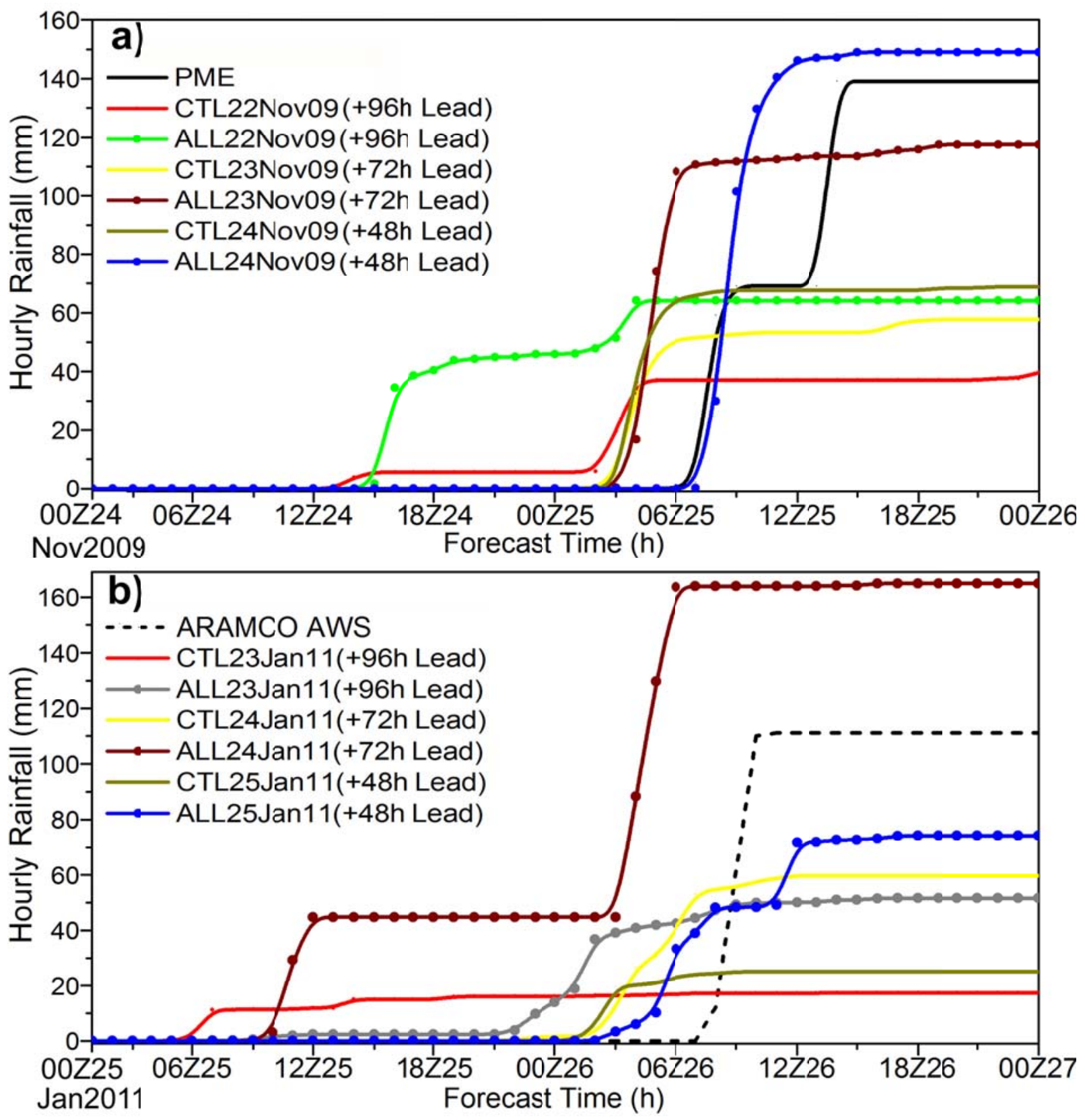

19) Time series of observed and simulated hourly rainfall for the retrospective experiments with lead times of 48, 72 and 96-h at a) PME synoptic station of Jeddah during 24-26 November 2009; b) ARAMCO AWS location, South of Jeddah during 25- 27 January 2011.

This article is protected by copyright. All rights reserved. 


\section{Table Captions}

1) Details of list of conducted experiments along with the assimilation cycles and the type of observations used for the 2009 event.

2) Details of retrospective lead-time experiments conducted for the 2009 and 2011 events.

3) Multi threshold rainfall analysis (model versus radar rainfall estimates) for the two studied rainfall events 


\begin{tabular}{|c|c|c|c|c|}
\hline Experiment & $\begin{array}{l}\text { First } \\
\text { guess }\end{array}$ & Cycling hours & $\begin{array}{l}\text { Assimilation } \\
\text { period }\end{array}$ & $\begin{array}{c}\text { Types of } \\
\text { observations } \\
\text { assimilated }\end{array}$ \\
\hline CTL & $\begin{array}{c}\text { GFS } \\
0.5^{\circ} \times 0.5^{\circ}\end{array}$ & No & No & Nil \\
\hline VARSFC & $\begin{array}{l}\text { WRF 6-h } \\
\text { forecast }\end{array}$ & \begin{tabular}{|c|} 
0600, 1200, 1800 UTC \\
23 November 2009 and \\
0000 UTC 24 November \\
2009 \\
\end{tabular} & 24-hours & $\begin{array}{l}\text { Synop, Metar, Ships, } \\
\text { QSCAT and Buoy }\end{array}$ \\
\hline VARAMV & $\begin{array}{l}\text { WRF 6-h } \\
\text { forecast }\end{array}$ & \begin{tabular}{|c|} 
0600, 1200,1800 UTC \\
23 November 2009 and \\
0000 UTC 24 November \\
2009 \\
\end{tabular} & 24-hours & GEO-AMV \\
\hline VARRAD & $\begin{array}{l}\text { WRF 6-h } \\
\text { forecast }\end{array}$ & $\begin{array}{c}\text { 0600, 1200, } 1800 \text { UTC } \\
23 \text { November } 2009 \text { and } \\
\text { 0000 UTC } 24 \text { November } \\
2009\end{array}$ & 24-hours & AMSU A and B \\
\hline VARPRO & $\begin{array}{l}\text { WRF 6-h } \\
\text { forecast }\end{array}$ & \begin{tabular}{|c|} 
0600, 1200,1800 UTC \\
23 November 2009 and \\
0000 UTC 24 November \\
2009 \\
\end{tabular} & 24-hours & $\begin{array}{c}\text { Sounding } \\
\text { observations from } \\
\text { Radiosonde and } \\
\text { Pilot Balloon } \\
\end{array}$ \\
\hline VARALL & $\begin{array}{l}\text { WRF 6-h } \\
\text { forecast }\end{array}$ & $\begin{array}{c}\text { 0600, 1200, } 1800 \text { UTC } \\
23 \text { November } 2009 \text { and } \\
\text { 0000 UTC } 24 \text { November } \\
2009\end{array}$ & 24-hours & $\begin{array}{c}\text { All GTS } \\
\text { observations } \\
\text { (SFC+AMV+PRO+ } \\
\text { RAD) }\end{array}$ \\
\hline
\end{tabular}

Table 1. Details of list of conducted experiments along with the assimilation cycles and the type of observations used for the 2009 event.

This article is protected by copyright. All rights reserved. 


\begin{tabular}{|c|c|c|c|c|}
\hline \multirow{7}{*}{$\begin{array}{c}25 \\
\text { November } \\
2009\end{array}$} & \begin{tabular}{|c|c}
$\begin{array}{c}\text { Lead- } \\
\text { time }\end{array}$ \\
\end{tabular} & Experiment & Cycling hours & $\begin{array}{c}\text { Initialization and } \\
\text { Ending time }\end{array}$ \\
\hline & \multirow{2}{*}{ 96-h } & CTL & Nill & $\begin{array}{c}0000 \text { UTC } 22-0000 \text { UTC } \\
26 \text { November } 2009\end{array}$ \\
\hline & & VARALL & 24-hour & $\begin{array}{c}0000 \text { UTC } 21-0000 \text { UTC } \\
26 \text { November } 2009\end{array}$ \\
\hline & \multirow{2}{*}{$72-\mathrm{h}$} & CTL & Nill & $\begin{array}{c}0000 \text { UTC } 23-0000 \text { UTC } \\
26 \text { November } 2009\end{array}$ \\
\hline & & VARALL & 24-hour & $\begin{array}{c}0000 \text { UTC } 22-0000 \text { UTC } \\
26 \text { November } 2009\end{array}$ \\
\hline & \multirow{2}{*}{ 48-h } & CTL & Nill & $\begin{array}{c}0000 \text { UTC } 24-0000 \text { UTC } \\
26 \text { November } 2009\end{array}$ \\
\hline & & VARALL & 24-hour & $\begin{array}{c}0000 \text { UTC } 23-0000 \text { UTC } \\
26 \text { November } 2009\end{array}$ \\
\hline & \multirow{2}{*}{ 96-h } & CTL & Nill & $\begin{array}{c}0000 \text { UTC } 23-0000 \text { UTC } \\
27 \text { January } 2011\end{array}$ \\
\hline & & VARALL & 24-hour & $\begin{array}{c}0000 \text { UTC } 22-0000 \text { UTC } \\
27 \text { January } 2011 \\
\end{array}$ \\
\hline $\begin{array}{c}26 \\
\text { January }\end{array}$ & \multirow{2}{*}{ 72-h } & CTL & Nill & $\begin{array}{c}0000 \text { UTC } 24-0000 \text { UTC } \\
27 \text { January } 2011 \\
\end{array}$ \\
\hline 2011 & & VARALL & 24-hour & $\begin{array}{c}0000 \text { UTC } 23-0000 \text { UTC } \\
27 \text { January } 2011\end{array}$ \\
\hline & \multirow{2}{*}{$48-h$} & CTL & Nill & $\begin{array}{c}0000 \text { UTC } 25-0000 \text { UTC } \\
27 \text { January } 2011 \\
\end{array}$ \\
\hline & & VARALL & 24-hour & $\begin{array}{c}0000 \text { UTC } 24-0000 \text { UTC } \\
27 \text { January } 2011 \\
\end{array}$ \\
\hline
\end{tabular}

Table 2. Details of retrospective lead-time experiments conducted for the 2009 and 2011 events.

This article is protected by copyright. All rights reserved. 


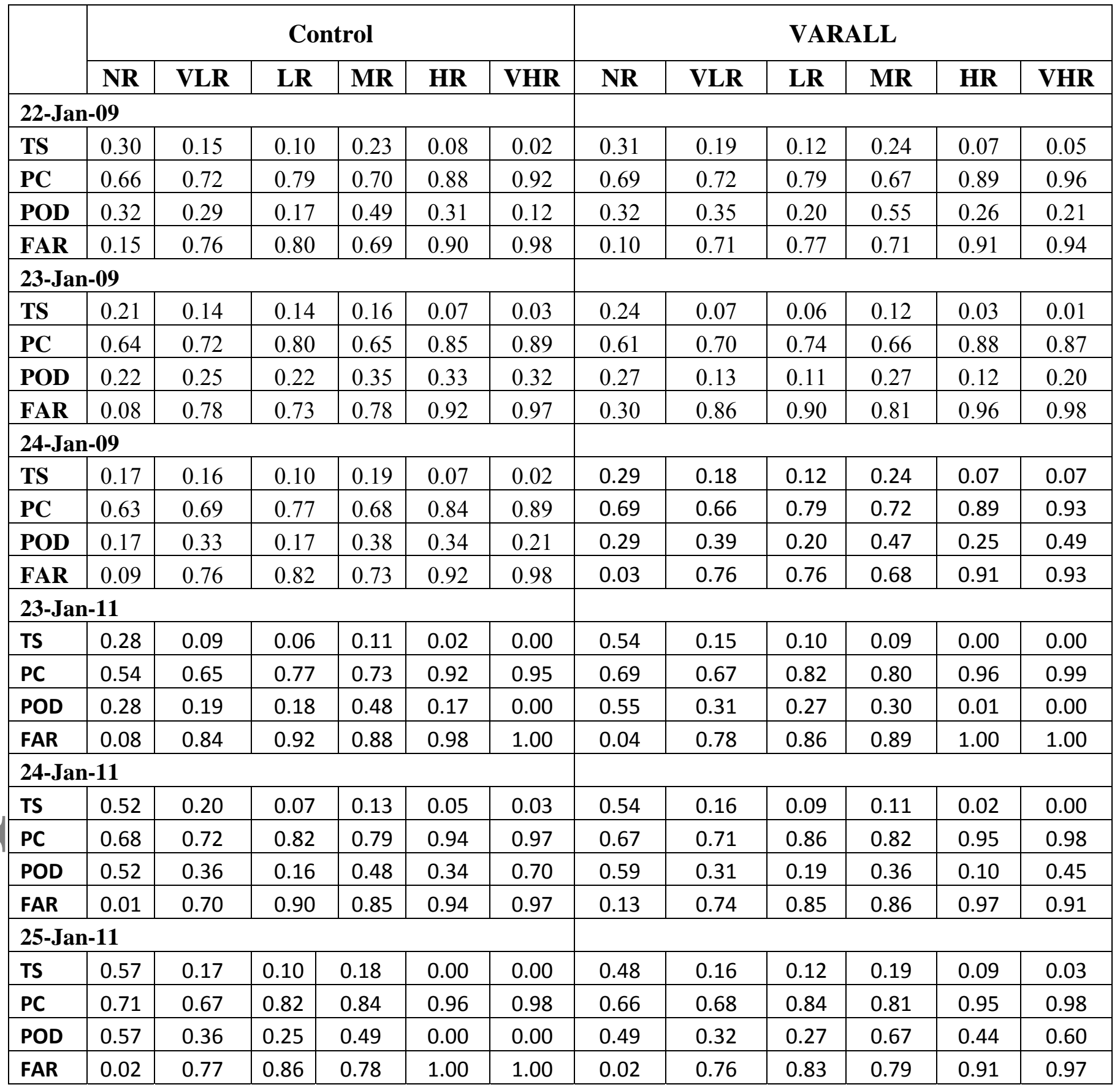

Table 3. Multi threshold rainfall analysis for the two retrospective forecast experiments

This article is protected by copyright. All rights reserved. 